Application of different techniques on stone fruit (Prunus spp.) drying and assessment of physical, chemical and biological properties: Characterization of dried fruit properties

Anita Vakula ${ }^{a}$, Aleksandra Tepić Horecki ${ }^{a}$, Branimir Pavlića, Marija Jokanovića, Vladislav Ognjanov $^{b}$, Maja Milovićc ${ }^{b}$ Nemanja Teslićc, Giuseppina Parpinellod, Marlies Decleer ${ }^{\mathrm{e}, \mathrm{f}}$, Zdravko Šumića*

aUniversity of Novi Sad, Faculty of Technology Novi Sad, Bulevar cara Lazara 1, 21000 Novi Sad, Serbia

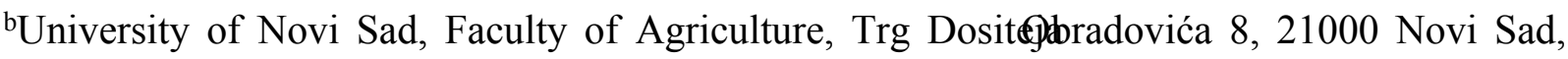
Serbia

'University of Novi Sad, Institute of Food Technology, Bulevar cara Lazara 1, 21000 Novi Sad, Serbia

dUniversity of Bologna, Department of Agricultural and Food Sciences, Piazza Goidanich 60, 47521 Cesena (FC), Italy

${ }^{\mathrm{e}}$ Ghent University, Faculty of Bioscience Engineering, Laboratory of Food Microbiology and Food Preservation, Belgium

${ }^{\mathrm{f} G h e n t ~ U n i v e r s i t y, ~ F a c u l t y ~ o f ~ P h a r m a c e u t i c a l ~ S c i e n c e s, ~ L a b o r a t o r y ~ o f ~ F o o d ~ A n a l y s i s, ~ B e l g i u m ~}$

*Corresponding author:

E-mail: sumic@uns.ac.rs, Telephone: +381 21485 3718, https://orcid.org/0000-0002-9770-0139

This is the peer reviewed version of the following article: Application of different techniques on stone fruit (Prunus spp.) drying and assessment of physical, chemical and biological properties:

Characterization of dried fruit properties, by Anita Vakula, Aleksandra Tepić Horecki, Branimir Pavlić, Marija Jokanović, Vladislav Ognjanov, Maja Milović, Nemanja Teslić, Giuseppina Parpinello, Marlies Decleer, Zdravko Šumić, which has been published in final form in Journal of Food Processing and Preservation Volume 45, Issue 2, February 2021, e15158, DOI https://doi.org/10.1111/jfpp.15158. This article may be used for non-commercial purposes in accordance with Wiley Terms and Conditions for Use of Self-Archived Versions. 


\begin{abstract}
Drying of stone fruit with different techniques and characterization of physical, chemical and biological properties of convective dried, vacuum dried and lyophilised stone fruit, as well as analysing and structuring the data sets by principal component analysis (PCA) were obtained in this paper. Drying technique significantly influenced the shear force, hardness, springiness and cohesiveness of dried apricot NS4 (Novi Sad 4) samples $(p<0.05)$; the total phenolic, flavonoid and monomeric anthocyanin content of dried sour cherry Feketicka, sweet cherry Lapins, sweet cherry Sweet Heart and plum Toptase samples and also the antioxidant capacity of dried sour cherry Feketicka, plum Anna Spath and peach Lela samples. The most noticeable differentiations of the stone fruit groups of samples dried with convective and vacuum drying and lyophilisation were observed in raw and dried sour cherry Feketicka and Erdi Botermo samples.
\end{abstract}

Keywords: stone fruit; physical, chemical and biological properties; drying techniques; principal component analysis.

\title{
Practical applications
}

The results and conclusions obtained in this research have various application in food industry in many aspects. First, part of the fruit varieties investigated in this study were developed at the Faculty of Agriculture and their application in the fruit drying industry has been thoroughly investigated. In addition, application of different drying techniques on different stone fruit species were applied in this research. Finally, the possibilities of preservation the most important quality indicators of dried fruit was observed. The impact of obtained conclusions and results in the field of agricultural and food industry is significant, since they could be applied in the industrial processes. 
DR. ALEKSANDRA N. TEPIĆ HORECKI (Orcid ID : 0000-0002-2479-0313)

DR. BRANIMIR PAVLIC (Orcid ID : 0000-0002-3551-7478)

DR. ZDRAVKO M. ŠUMIĆ (Orcid ID : 0000-0002-9770-0139)

Article type : Original Article

\section{Introduction}

Sour cherry ( $P$. cerasus), sweet cherry $(P$. avium), apricot ( $P$. armeniaca), plum $(P$. domestica) and peach (P. persica) are the most prevalent stone fruit in Serbia. First matured are sour and sweet cherries which are followed by apricots, plums and peaches (Wills, Scriven, \& Greenfield, 1983). Due to their widespreadness, good processing potential and good sensory and nutritional characteristics, certain varieties of stone fruit have been investigated by many authors (Esti, Cinquanta, Sinesio, Moneta, \& Di Matteo, 2002; Toğrul \& Pehlivan, 2003; Vargas, Jablonski, Flôres, \& Rios, 2017; Wojdyło, Figiel, Lech, Nowicka, \& Oszmiański, 2014). Stone fruit has been investigated also in the field of application of different extraction techniques, such as for example paper by Garofulić, Dragović-Uzelac, Jambrak and Jukić (2013) the effect of microwave assisted extraction on the isolation of anthocyanins and phenolic acids from sour cherry Marasca was observed. Furthermore, in the paper by Zaghdoudi et al. (2015) accelerated solvent extraction of carotenoids from peach, apricot, among other fruit, were investigated while conventional and ultrasound-assisted extraction of anthocyanins from blackberry and sweet cherry cultivars were described in the paper by Oancea, Grosu, Ketney and Stoia (2013).

The consumption of stone fruit can bring many benefits for human health since fruit in general is rich in bioactive compounds such as phenolic compounds (Tomás-Barberán et al., 2001), anthocyanins, carotenoids, vitamin C and organic acids (Wills et al., 1983). However, 
the amount of bioactive compounds in fresh fruit, as well as in certain fruit product, is influenced by their stability which is related to their oxidation and environmental sensitivity (Leong \& Oey, 2012). Valuable components of stone fruit made it prevalent raw material of processing industry.

In order to extend the shelf life and its usage throughout the year, fruit is usually preserved with drying, freezing or made into jams, compotes or juices. One of the ways of food preservation is the reduction of the water availability (Mulet, Cárcel, Sanjuan, \& Bon, 2003). During the drying process, water from the raw material, which is necessary for microorganism's growth and enzymatic activity, has been removed. This prevents the growth of microorganisms since the minimum water activity at which microorganisms can grow is 0.60 (Beuchat et al., 2013). Many enzymes will function minimally in the $0.65-0.70$ range (Lopez et al. 1997) which indicates that lower water activity results in reduced enzyme activity. Drying process has also been used prior to extraction of secondary metabolites from different plants such as for example applied and described in the paper by Rangkadilok et al. (2007) where evaluation of free radical scavenging and antityrosinase activities of standardized longan fruit extract and thus one part of the fruit was dried before extraction process. Also in the paper by Assefa and Keum (2017) different drying methods (microwave, oven-, freeze-, and air-drying) were applied for yuzu (Citrus junos Sieb ex Tanaka) drying prior to extraction of polyphenols and antioxidants.

The commonly used type of drying in the food industry is convective drying process with hot air (Mujumdar \& Beke, 2003). However, the presence of oxygen and high temperatures involved in drying process negatively influence physical, chemical and biological properties of dried products (Larrosa, Cadaval, \& Pinto, 2015). Also, drying usually precedes extraction processes in order to reduce water content and to preserve polyphenol content and so undesirable drying conditions may influence degradation of bioactive compounds which could further lead to lower extraction yields. On the other hand, application of high temperatures during drying may influence release of bounded polyphenols (Papoutsis et al., 2018). But, also when high temperatures are applied part of the polyphenols might be oxidized and converted to other compounds (Abhay, Hii, Law, Suzannah, \& Djaeni, 2016) Disadvantages of convective drying, in terms of negative influence of oxygen presence and high applied temperatures could be successfully solved by using vacuum drying technique. During vacuum drying, applied vacuum decreases the pressure in the chamber at the given temperature and the water vapour has constantly being removed from vacuum chamber 
(Bourdoux, Li, Rajkovic, Devlieghere, \& Uyttendaele, 2016). Combinations of vacuum drying with infrared, ultrasound or microwave drying were investigated by Chen, Guo and $\mathrm{Wu}, 2016$; Pu and Sun 2016; Xie et al. 2017. The type of vacuum drying which includes sublimation process is freeze drying or lyophilisation. Beside all advantages relative to vacuum and convective drying, lyophilisation is not commonly used for fruit drying due to higher drying cost and energy consumption and low efficiency (Pei et al., 2014).

Even though, stone fruit and their products were thoroughly investigated (Aghbashlo, Kianmehr, \& Hassan-Beygi, 2010; Celik, Demirkol, Durmus, \& Tarakci, 2020; Doymaz, 2014; Doymaz \& İsmail, 2011; Goyal, Kingsly, Manikantan, \& Ilyas, 2007; Ihns, Diamante, Savage, \& Vanhanen, 2011; Ouaabou et al., 2020), in known and accessible databases there are no papers investigating different types of fruit, drying techniques and characterization of the most important quality of dried products in the framework of a single research. Encouraged with these facts, authors' main goal was drying of two varieties of each stone fruit type and characterization of their physical, chemical and biological properties. Furthermore, another goal was to compare physical, chemical and biological properties in terms of applied drying techniques on the one hand and in terms of certain variety of each type of stone fruit on the other, by PCA utilization.

\section{Materials and Methods}

\section{Samples}

Fresh stone fruit samples were purchased at the Faculty of Agriculture, University of Novi Sad. Two varieties of each type: sour cherry (Feketicka (SCF) and Erdi Botermo (SCEB)); sweet cherry (Lapins (SCL) and Sweet Heart (SCSH)); apricot (Buda (AB) and NS4 (ANS4)); plum (Anna Spath (PAS) and Toptaste (PTT)) and peach (Lela (PL) and Fairtime (PFT)) were collected from the experimental field of Faculty of Agriculture, Novi Sad, at Rimski Šančevi (Serbia).

After the measuring of flesh/stone ratio and mass per unit area, samples were prepared for each type of drying. The stones were carefully moved from each sample. Sour and sweet cherries were dried directly while apricots and peaches were first cut on two halves and four quarters, respectively. Samples intended for convective and vacuum drying were not frozen 
previously, while for lyophilisation samples were frozen and stored at $-20{ }^{\circ} \mathrm{C}$ until drying. For each drying, $300 \mathrm{~g}$ of the sample was measured.

Investigated properties of fresh stone fruit samples are given in supplementary material (Table S1).

Chemicals

The following reagents were purchased from Sigma-Aldrich Chem (Steinheim, Germany): Folin-Ciocalteu reagent, $( \pm)$-catechin, gallic acid, 2,2-diphenyl-1-picrylhydrazyl (DPPH), ABTS (2,2'-azino-bis-(-3-ethylbenzothiazoline-6-sulfonic acid) diammonium salt), TPZT (2,4,6-tris(2-pyridyl)-s-triazine), iron (III)-chloride and Iron (II)-sulfatheptahydrate and potassium persulfate. Trolox (6-hydroxy-2,5,7,8-tetramethylchroman-2-carboxylic acid) was purchased from Sigma-Aldrich (Milano, Italy). Sodium acetate and hydrochloric acid were obtained from Merck (Darmstadt, Germany). Formic acid was obtained from VWR International (Milan, Italy). Acetonitrile (HPLC grade and LC-MS grade), methanol (absolute, LC-MS grade) and glacial formic acid (99\%, ULC-MS) were purchased from BioSolve BV (Valkenswaard, the Netherlands). Ammonium acetate was obtained from Merck (Darmstadt, Germany). Methanol (HiPerSolv Chromanorm HPLC grade) was supplied by VWR International (Zaventem, Belgium). Ultrafree ${ }^{\circledR}-\mathrm{MC}$ centrifugal filter devices $(0.22 \mu \mathrm{m})$ were supplied by Millipore (Bredford, MA, USA). Water was purified on a Milli-Q ${ }^{\circledR}$ SP Reagent water system from Millipore Corp (Brussels, Belgium). Valinomycin (VAL) (10 mg, solid standard) and beauvericin (BEA), enniatins (ENN) (A, A1, B, B1) (1 $\mathrm{mg}$, solid standard) were purchased from Sigma-Aldrich (Diegem, Belgium).

All other chemicals were of analytical and HPLC grade.Experimental design

Experimental design and used are presented in Figure 1 and Table 1, respectively. A total of forty stone fruit samples, each weighing $300 \mathrm{~g}$, were used in experiments. ten fresh $(\mathrm{F})$ samples (SCF-F, SCEB-F, SCL-F, SCSH-F, AB-F, ANS4-F, PAS-F, PTT-F, PL-F, PFT-F), ten samples dried by convective drying (C) (SCF-C, SCEB-C, SCL-C, SCSH-C, AB-C, ANS4-C, PAS-C, PTT-C, PL-C, PFT-C), ten samples dried by vacuum drying (V) (SCF-V, SCEB-V, SCL-V, SCSH-V, AB-V, ANS4-V, PAS-V, PTT-V, PL-V, PFT-V) and ten samples dried by lyophilisation (L) (SCF-L, SCEB-L, SCL-L, SCSH-L, AB-L, ANS4-L, PAS-L, PTT-L, PL-L, PFT-L). 
Independent variables were temperature, pressure and time during drying which are presented in Table 2 for each sample. Dependent variables were four physical parameters: moisture content $(\mathrm{MC})$, water activity $\left(\mathrm{a}_{\mathrm{w}}\right)$, total colour change $(\Delta \mathrm{E})$, texture (shear force, penetration force, hardness, springiness, cohesiveness and chewiness); three chemical parameters: total phenolic (TPC), flavonoid (TFC) and monomeric anthocyanin content (TMAC) and one biological parameter (antioxidant capacity (FRAP, DPPH and ABTS test)). Also, toxin analysis (BEA and ENNs (A, A1, B, B1)) were performed on fresh and dried samples. The number of repetition has been mentioned for each analyse separately.

Figure 1. Experimental design-flow chart

Table 1. Fresh and dried stone fruit-abbreviations

Drying techniques

Vacuum drying process was described in detail by Šumić, Tepić, Vidović, Jokić, \& Malbaša (2013), while convective drying and lyophilisation procedures have been described in detail by Šumić et al. (2016). Vacuum and convective drying was continued until no mass change was detected (final moisture content in equilibrium). The conditions of applied drying methods are presented in Table 2.

Table 2. Conditions of convective drying, vacuum drying and lyophilisation.

Analyses

-Texture analysis

Instrumental texture measurements were performed using a Texture Analyser (TE32, Stable Micro Systems, UK). Preparation of fresh samples for texture analysis was the same as preparation for drying process, explained in detail in section Samples (Material and Methods). For dried sour and sweet cherry samples there were also no special preparations, while dried apricot, plum and peach samples were cut in pieces dimensions $2 \mathrm{~cm} \times 2 \mathrm{~cm} \times 1$ 
$\mathrm{cm}$. All texture analyses were performed at room temperature. The texture analyses were performed twelve times for statistical purpose.

Shearing Test

The shear force was measured using Craft Knife Adapter. Instrumental settings for shear force analyses were the following: test speed $-1.0 \mathrm{~mm} / \mathrm{s}$; load cell $-5 \mathrm{~kg}$. Shear force has been expressed as force $(\mathrm{g})$ required for cutting of the samples.

\section{Penetration Test}

The penetration test was carried using $2 \mathrm{~mm}$ stainless Cylinder probes. Instrumental settings: test speed $-2.0 \mathrm{~mm} / \mathrm{s}$; load cell $-5 \mathrm{~kg}$ were set for penetration force analysis. The sample was positioned centrally relative to the Cylinder probe. Penetration force has been expressed as force $(\mathrm{g})$ required for penetration through the samples.

Texture Profile Analysis (TPA)

Texture profile analysis (TPA) was performed as described by Bourne (1978), using Texture Analyser (TE32, Stable Micro Systems, UK) equipped with a cylindrical plate of $36 \mathrm{~mm}$ in diameter. Dried samples were compressed twice to $40 \%$ of their original thickness at a constant speed of $1 \mathrm{~mm} / \mathrm{s}$. Hardness, springiness, cohesiveness and chewiness were determined by using TPA test. Hardness and chewiness were expressed as force ( $\mathrm{g}$ ) necessary for sample compression unit, while springiness and cohesiveness are dimensionless values. Hardness was defined by peak force during the first compression cycle; springiness as the rate at which a deformed sample goes back to its undeformed condition after the deforming force is removed; cohesiveness was calculated as the ratio of the area under the second curve to the area under the first curve and chewiness was obtained by multiplying hardness, cohesiveness, and springiness (Bianchi et al., 2016).

\section{-Antioxidant capacity assays}

Approximately $10 \mathrm{~g}$ of fresh and $5 \mathrm{~g}$ of dried stone fruit samples were ground in a blender before the extraction. Grounded samples were transferred to a volumetric flask and $50 \mathrm{~mL}$ of methanol, as extraction solvent, was added. Extraction was carried out for $24 \mathrm{~h}$ at the room temperature. The obtained extracts were filtered, placed into a glass bottles and stored to prevent oxidative damage until analysis.

FRAP assay 
The sample ability to reduce $\mathrm{Fe}^{3+}$ was measured using slightly modified method firstly presented by Benzie and Strain (1996). The FRAP reagent was freshly prepared from 300 $\mathrm{mM}$ acetate buffer (pH=3.6), $10 \mathrm{mM}$ 2,4,6-tris(2-pyridyl)-s-triazine (TPZT) in $40 \mathrm{mM} \mathrm{HCl}$ solution and $20 \mathrm{mM} \mathrm{FeCl}_{3}$ aqueous solution. Solutions were mixed in ratio 10:1:1 (v/v/v). Previously diluted extracts and FRAP reagent were mixed $(0.1 \mathrm{~mL}+1.9 \mathrm{~mL})$ and stored to incubate in the dark at $37{ }^{\circ} \mathrm{C}$ for $10 \mathrm{~min}$. The measurements were performed at $593 \mathrm{~nm}$, in duplicates, with UV-VIS spectrophotometer (Cary 60, Agilent Technologies, Santa Clara, USA). The results were finally reported as $\mathrm{mg}$ of $\mathrm{Fe}^{2+}$ equivalents per $\mathrm{g}$ of dry weight.

DPPH assay

The sample ability to scavenge 2,2-diphenyl-1-picrylhydrazyl free radicals (DPPH) was measured using a modified method originally presented by Brand-Williams, Cuvelier and Berset, et al. (1995). Briefly, methanolic solution of the DPPH reagent (65 $\mu \mathrm{M})$ was freshly prepared and adjusted with methanol to reach absorbance of $0.70( \pm 0.02)$. DPPH reagent and previously diluted extracts were mixed $(2.9 \mathrm{~mL}+0.1 \mathrm{~mL})$ in the $10 \mathrm{~mm}$ plastic cuvettes and incubated at room temperature for $60 \mathrm{~min}$. Free radical scavenging measurements were performed at $517 \mathrm{~nm}$, in duplicates with UV-VIS spectrophotometer (Cary 60, Agilent Technologies, Santa Clara, USA). The obtained results were reported as mg of Trolox equivalents per g of dry weight.

\section{ABTS assay}

The ABTS free radical scavenging ability of samples was measured using a modified method originally described by $\operatorname{Re}$ et al. (1999). ABTS stock solution was freshly prepared from mixture $(1: 1, \mathrm{v} / \mathrm{v})$ of $2.45 \mathrm{mM}$ potassium persulfate aqueous solution and $7 \mathrm{mM}$ ABTS $(2,2$ ' azino-bis-(-3-ethylbenzothiazoline-6-sulfonic acid) diammonium salt) aqueous solution and left in the dark at room temperature for $16 \mathrm{~h}$. A stock solution was diluted using $300 \mathrm{mM}$ acetate buffer $(\mathrm{pH}=3.6)$ to an absorbance of $0.70( \pm 0.02)$. Previously diluted extracts and ABTS reagent were mixed $(0.1 \mathrm{~mL}+2.9 \mathrm{~mL})$ and stored in the dark at room temperature for 300 minutes. The measurements were performed at $734 \mathrm{~nm}$, in duplicates with UV-VIS spectrophotometer (Cary 60, Agilent Technologies, Santa Clara, USA). The results were finally reported as $\mathrm{mg}$ of Trolox equivalents per $\mathrm{g}$ of dry weight.

\section{-Total phenolics content}

The content of total phenolic content in methanolic extracts was determined by FolinCiocalteu procedure (Singleton and Rossi, 1965), using gallic acid as a standard. Content of 
total phenolic content has been expressed as mg of gallic acid equivalent per $100 \mathrm{~g}$ of dry weight of samples (mg GAE/100 g DW). Experiments were replicated three times and results are expressed as mean values. Absorbance was measured at $765 \mathrm{~nm}$.

The UV/Vis spectrophotometer (model 6300 Spectrophotometer, Jenway, UK) was used for all spectrophotometric methods.

\section{-Toxin Analysis}

Primary stock solutions were prepared by dissolving the solid standard in acetonitrile (1 $\mathrm{mg} / \mathrm{mL}$ ). All stock solutions, except VAL, were stored at $-20{ }^{\circ} \mathrm{C}$. VAL was stored at $4{ }^{\circ} \mathrm{C}$. Working solutions of $10 \mu \mathrm{g} / \mathrm{mL}$ were prepared in acetonitrile and then stored at $4{ }^{\circ} \mathrm{C}$ and renewed monthly. Mixture solutions (BEA and ENNs) were prepared prior to each experiment by diluting the working solution in acetonitrile. Initially, $2 \mathrm{~g}$ of fresh and dried stone fruit samples were homogenized and transferred into $50 \mathrm{~mL}$ extraction tubes. The method for toxin analysis is explained in detail in the paper by Decleer, Rajkovic, Sas, Madder and De Saeger (2016).

Description of analysis (moisture content, water activity, total colour change, total flavonoid content and monomeric anthocyanin content) is shown in detail by Tepić-Horecki et al. (2018).

Statistical analysis

All the data were analysed by univariate analysis of variance (ANOVA, $p<0.05$ ) in order to differentiate the samples using an $\alpha=0.05$ criterion and Tukey's Multiple Comparison Test. Principal Component Analysis (PCA) was applied in order to analyse and structurize the obtained results. Statistica 10.0 (StatSoft Inc., Tulsa, OK, USA) was used both for the PCA and ANOVA.

\section{Results and Discussion}

Physical, chemical and biological characterization has been performed in stone fruit dried with convective drying, vacuum drying and lyophilisation. Dried stone fruit characterization was observed by measuring $\mathrm{MC}$, aw, $\Delta \mathrm{E}$, texture analysis (shear force, penetration force, 
hardness, springiness, cohesiveness and chewiness), TPC, TFC, TMC, antioxidant capacity (FRAP, DPPH and ABTS test) and toxin analysis (BEA and ENNs (A, A1, B, B1)).

Deviations are a normal occurrence in the case of technological processing of different plant material with usage of completely different techniques. For this reason, several iterations were performed and the results were statistically processed in order to make conclusions with the statistically defined security that are discussed for each individual parameter in this part of the paper.

\subsection{Physical properties}

\subsubsection{Moisture content (MC) (Table 3)}

In dried SCEB and SCL samples drying techniques significantly influenced $(p<0.05)$ the MC. It could be seen that, both for sour and sweet cherry samples, the lowest and the highest MC were obtained in convective and vacuum dried samples, respectively. In apricot and peach samples, ANS4 and PFT, respectively, it was not noticed significant difference of MC $(p<0.05)$ between convective and vacuum dried samples. It was also noticed that in both plum varieties (PTT and PAS) and in peach PL samples, drying techniques significantly influenced the MC.

\subsubsection{Water activity $\left(\mathrm{a}_{\mathrm{w}}\right)$ (Table 3$)$}

It could be seen that drying techniques influenced $\mathrm{a}_{\mathrm{w}}$ values in all types and varieties of stone fruit. The lowest $a_{w}$ values in all types of dried fruit were obtained in lyophilised samples (SCEB-L, SCSH-L, ANS4-L, PTT-L, PL-L) and the highest ones were obtained in vacuum dried samples (SCEB-V, SCL-V, AB-V, PAS-V, PL-V).

\subsubsection{Total colour change $(\Delta \mathrm{E})$ (Table 3)}


In dried sour cherry samples, the lowest $\Delta \mathrm{E}$ was obtained in convective dried samples (SCF$\mathrm{C}$ and SCEB-C), while the highest $\triangle \mathrm{E}$ was observed in lyophilised samples (SCF-L and SCEB-L). Concerning these results, it was assumed that in case of drying sour cherry samples (SCF and SCEB), pre-freezing of fruit and long drying time, significantly influenced the increase of $(p<0.05) \Delta \mathrm{E}$, beside the absence of oxygen and low temperatures. Significantly different $(p<0.05)$ values of $\triangle \mathrm{E}$ were obtained between SCL-V and SCSH-V sweet cherry varieties. Namely, in SCL and SCSH varieties, the lowest $\triangle \mathrm{E}$ values were obtained in vacuum dried and lyophilised samples, respectively, while the highest $\Delta \mathrm{E}$ values were noticed in lyophilised and convective dried samples, respectively. In dried apricot samples $\mathrm{AB}$ and also in peach samples PL it was noticed that applied drying techniques significantly influence $(p<0.05) \Delta \mathrm{E}$. The value of $\Delta \mathrm{E}$ of vacuum dried peaches, obtained by Kwon, Kim and Youn (2013), was 14.31 which is higher than $\Delta \mathrm{E}$ obtained for PL-V sample (7.39) and lower than $\triangle \mathrm{E}$ observed for PFT-V sample (36.92). Both in dried AB and ANS4 samples, the lowest $\Delta \mathrm{E}$ values were obtained in vacuum dried samples (AB-V and ANS4-V), while the highest values of $\Delta \mathrm{E}$ were observed in lyophilised samples (AB-L and ANS4-L).

Table 3. Experimentally obtained values of $M C, a_{w}$ and $\Delta E$ of dried samples.

\subsubsection{Texture analysis}

\section{Shear force (Table 4)}

The lowest shear force obtained in all dried samples was $147.4 \mathrm{~g}$ (ANS4-L), while the highest one was noticed in PTT-L sample (3856.7 g). It could be seen that both the highest and the lowest values of shear force of all dried samples were observed in lyophilised samples. Applied drying techniques significantly influenced $(p<0.05)$ the shear force of ANS4 samples.

Penetration force (Table 4)

It could be seen that in all convective dried samples $5000 \mathrm{~g}$ penetration force was observed. However, all these samples were too hard for penetration by sphere of instrument. Since the weight of $5000 \mathrm{~g}$ was used during measurement, all values for penetration force were noticed 
as $>5000 \mathrm{~g}$. In different varieties of the same type of plum fruit, the lowest and the highest penetration force were observed, PTT-V (509.3 g) and PAS-L (2852.9 g), respectively. Based on the obtained results for dried SCEB, SCL, SCSH, PTT, PAS, PL and PFT samples, drying techniques significantly influenced $(p<0.05)$ the penetration force.

Hardness (Table 4)

Hardness, as primary texture property, is defined as force necessary to attain a given deformation (Szczesniak, 2002). PAS-V and PTT-C were the samples with the lowest (252.4 g) and the highest (6377.8 g) hardness of all dried samples. Drying techniques significantly influenced $(p<0.05)$ the hardness of SCSH and ANS4 samples.

Springiness (Table 4)

Springiness is defined as rate at which a deformed material goes back to its undeformed condition after the deforming force is removed (Szczesniak, 2002). Springiness of fresh samples varied between 0.29 (ANS4-F) and 0.94 (SCF-F), while in dried samples this range was between 0.28 (PFT-L) and 0.80 (SCF-C). Based on the observed results for dried SCF, SCL and ANS4 samples, drying techniques significantly influenced $(p<0.05)$ the springiness.

Cohesiveness (Table 4)

The extent to which a material can be deformed before it ruptures defines the cohesiveness parameter (Szczesniak, 2002). The lowest cohesiveness of fresh samples was obtained in PLF sample (0.13), while cohesiveness obtained for PAS-F sample was the highest $(0.71 \mathrm{~g})$. The lowest cohesiveness of all dried samples was $0.24 \mathrm{~g}$ obtained in ANS4-L sample, while the highest one $(0.95 \mathrm{~g})$ was noticed in PTT-L sample. It could be noticed that for dried samples ANS4 and PFT, drying techniques significantly influenced $(p<0.05)$ the cohesiveness.

Chewiness (Table 4)

Chewiness, a product of hardness, cohesiveness and springiness, is defined as energy required to masticate a solid food to a state ready for swallowing (Szczesniak, 2002). Chewiness of fresh samples varied between $26.5 \mathrm{~g}$ (ANS4-F) and $806.8 \mathrm{~g}$ (PTT-F), while in dried samples this range was between $79.4 \mathrm{~g}$ (AB-L) and $1637.5 \mathrm{~g}$ (SCEB-C). 
Table 4. Experimentally obtained values of dried samples texture.

\subsection{Chemical properties}

\subsubsection{Total phenolic content (TPC) (Figure 2.a)}

The lowest TPC of all investigated fresh samples was obtained in AB-F sample (194.94 mg GAE/100 g DW), while SCF-F was sample with the highest TPC (1713.23 mg GAE/100 g DW). TPC in sweet cherry, obtained by Serradilla et al. (2011) varied between 59.05 and 117 $\mathrm{mg}$ gallic acid/100 g raw weight. TPC of all dried samples varied between $199.27 \mathrm{mg}$ GAE/100 g DW obtained in AB-L sample and $1605.34 \mathrm{mg} \mathrm{GAE} / 100 \mathrm{~g} \mathrm{DW}$ noticed in SCFV sample. Drying techniques significantly influenced $(p<0.05)$ the TPC of dried SCF, SCL, SCSH, ANS4, PTT, PAS and PFT samples and also did not significantly influence $(p<0.05)$ TPC of AB samples. Kwon et al. (2013) applied cold vacuum drying on peaches and observed TPC of dried peach was $4.03 \mathrm{mg} \mathrm{GAE}$ (gallic acid equivalents)/g. The behaviour of the polyphenols compounds in cases when they are exposed to different drying conditions are presented in the paper by Papoutsis et al. (2018) and also described in the introduction part of this paper. Also, influence of different drying techniques on different types of plant material is described in papers by Alfaro, Mutis, Quiroz, Seguel, and Scheuermann (2014) and Heredia, Barrera and Andrés (2007) where effects of drying techniques on murtilla fruit polyphenols and antioxidant capacity drying of cherry tomato by a combination of different dehydration techniques were investigated, respectively.

Figure 2. Total phenolic (a), flavonoid (b) and monomeric anthocyanin (c) content observed in fresh, convective dried, vacuum dried and lyophilised samples.

\subsubsection{Total flavonoid contact (TFC) (Figure 2.b)}

As a subgroup of phenolic compounds, flavonoids contribute to antioxidant profile of fresh and dried fruit. Thus, these two parameters are often investigated together such as in research 
by Hooshmand and Arjmandi (2009) where phenolic and flavonoid content in dried plum powder was $22.4 \mathrm{mg} / 100 \mathrm{~g}$. Different drying parameters influence TFC preservation to a greater or lesser extent. TFC of fresh samples varied between $68.44 \mathrm{mg} \mathrm{CE} / 100 \mathrm{~g}$ DW (PASF) and $780.26 \mathrm{mg} \mathrm{CE} / 100 \mathrm{~g} \mathrm{DW}$ (SCF-F). It was noticed that both the highest values of TPC and TFC were observed in the same SCF-F sample. In dried samples AB-C and SCF-V, the lowest (92.42 mg CE/100 g DW) and the highest (824.32 mg CE/100 g DW) TFC contents, were obtained respectively. Based on the observed results for dried SCF, SCL, SCSH, AB, ANS4, PTT, PAS, PL and PFT samples, drying techniques significantly influenced $(p<0.05)$ the TFC.

\subsubsection{Total monomeric anthocyanin content (TMAC) (Figure 2.c)}

Content of anthocyanins, widely appeared red colorants of fruits and vegetables, were already investigated by Serradilla et al. (2011) where observed content of total content of these compounds varied between 4.06 and $39.44 \mathrm{mg}$-cyanidin-3-O-rutinoside/100 g raw weight. The lowest TMAC of fresh samples was obtained in PAS-F sample (1.07 mg CGE/100 g DW), while SCL-F was sample with the highest TMAC (46.31 mg CGE/100 g DW). TMAC of all dried samples varied between $0.29 \mathrm{mg}$ CGE/100 g DW obtained in PAS-C sample and $262.15 \mathrm{mg}$ CGE/100 g DW noticed in PTT-V sample. In dried SCF, SCEB, SCL, SCSH, ANS4 and PTT samples applied drying techniques significantly influenced $(p<0.05)$ the obtained TMAC.

\subsection{Biological properties}

\subsubsection{Antioxidant properties (Figure 3)}

Antioxidant capacity of fresh sweet cherries, obtained by Serradilla et al. (2011) was in the range from 317.92 to $439.10 \mathrm{mg}$ Trolox/100 g raw weight. Also, Wojdyło, Figiel, Lech, Nowicka and Oszmiański (2014) observed antioxidant capacity using FRAP and ABTS tests in fresh sour cherries (61.31 and $159.052 \mathrm{mg}$ Trolox/g DW respectively); convective dried sour cherries (from 31.807 to $41.591 \mathrm{mg}$ Trolox/g DW and from 80.348 and $119.589 \mathrm{mg}$ 
Trolox/g DW, respectively), vacuum-microwave dried sour cherries (from 36.860 to 47.458 $\mathrm{mg}$ Trolox/g DW and from 117.036 to $171.178 \mathrm{mg}$ Trolox/g DW, respectively) and lyophilised sour cherries (60.227 and $151.293 \mathrm{mg}$ Trolox/g DW). Three antioxidant tests, FRAP, DPPH and ABTS, were analysed in order to obtain antioxidant capacity of fresh and dried stone fruit.

FRAP test (Figure 3.a)

The lowest antioxidant capacity, obtained by FRAP test, of all investigated fresh samples was obtained in PAS-F sample $\left(0.1521 \mathrm{mg} \mathrm{Fe}^{2+} / \mathrm{g} \mathrm{DW}\right)$, while SCL-F was sample with the highest antioxidant capacity $(0.7197 \mathrm{mg} \mathrm{Fe} / \mathrm{g} \mathrm{DW})$. Antioxidant capacity of all dried samples was in the range from $0.1953 \mathrm{mg} \mathrm{Fe} \mathrm{Fe}^{2+} / \mathrm{g}$ DW obtained in PAS-V sample to $2.7481 \mathrm{mg} \mathrm{Fe}^{2+} / \mathrm{g} \mathrm{DW}$ noticed in the vacuum dried SCF-V sample. Drying techniques significantly influenced $(p<$ 0.05) the antioxidant capacity of dried SCF, AB, PTT, PAS and PL samples.

DPPH test (Figure 3.b)

Antioxidant capacity obtained by DPPH test in all fresh samples varied between $1.5947 \mathrm{mg}$ Trolox/g DW observed in PAS-F sample and $17.3361 \mathrm{mg}$ Trolox/g DW noticed in SCF-F sample. Antioxidant capacity of all dried samples was in the range from $1.6505 \mathrm{mg}$ Trolox/g DW obtained in AB-C sample to $26.7122 \mathrm{mg}$ Trolox/g DW observed in PTT-C sample. Based on the obtained results of dried SCF, ANS4, PAS, PL and PFT samples, it was noticed that drying techniques significantly influenced $(p<0.05)$ the antioxidant capacity.

ABTS test (Figure 3.c)

Antioxidant capacity obtained by ABTS test of investigated fresh fruit samples was in the range from $2.6720 \mathrm{mg}$ Trolox/g DW obtained in PAS-F sample to $11.7142 \mathrm{mg}$ Trolox/g DW noticed in SCL-F sample. Antioxidant capacity of all dried samples varied between 3.3675 mg Trolox/g DW obtained in SCF-V sample and $58.3583 \mathrm{mg}$ Trolox/g observed in PTT-C sample. It could be seen that drying techniques significantly influenced $(p<0.05)$ the antioxidant capacity of dried SCF, SCSH, ANS4, PTT, PAS and PL samples. 
Figure 3. Antioxidant capacity of fresh, convective dried, vacuum dried and lyophilised samples obtained by FRAP (a), DPPH (b) and ABTS (c) test.

Since FRAP, ABTS and DPPH assays present three different assays of the antioxidant capacity in terms of the different compounds that sample has ability to scavenge or reduce, it was chosen to analyse all three assays in order observe complete picture of the antioxidant profile of fresh and dried stone fruit samples. Compatibility between these assays are in accordance with the results obtained in papers by Maria do Socorro et al (2010); Popović, Štajner, Kevrešan, and Bijelić (2012) and Vakula, Šumić, Zeković, Tepić Horecki, Pavlić (2019).

Based on the Figure 2.a and Figures 2.a, b and c, it could be seen that the TPC content of most of the fresh and dried stone fruit samples are in accordance with all three investigated antioxidative tests (FRAP, DPPH and ABTS). There are also certain disagreements that could be explained with the fact that the phenolic compounds are just a part of the compounds which make the total antioxidant capacity in stone fruit samples. Other important compounds such as flavonoid and anthocyanins compounds, which are also investigated in this research also have important role in term of antioxidant profile of fresh and dried stone fruit. For this reason, all these compounds are chosen to be investigated in this paper, to make as complete picture as it is possible in terms of the quality properties of fresh and dried stone fruit samples. Accordingly, similar results in terms of the accordance between total phenolic content and antioxidant capacity are presented in the papers by Igual, García-Martínez, Martín-Esparza, and Martínez-Navarrete (2012); Madrau et al. (2009) and Sultana, Anwar, Ashraf, and Saari (2012).

\subsection{Toxin analysis}

Different types of toxins in various fruits were investigated by many authors (Drusch \& Ragab, 2003; MacDonald et al., 1999). The presence of emerging Fusarium mycotoxins 
(ENNs and BEA) was determined in samples of nuts and dried fruits commercialized in Valencia, by Tolosa, Font, Mañes, and Ferrer (2013). Based on the research by Tolosa et. al. (2013), the average levels of BEA and ENNs A, A1, B, B1 in dried fruit were 0.007, 0.242, $0.011,0.058,0.022 \mathrm{mg} / \mathrm{kg}$, respectively.

In this study, the presence of BEA and ENNs A, A1, B, B1 was investigated in fresh and dried stone fruit. Based on the obtained results, it was noticed that all fresh and dried samples were free of all investigated toxins.

\subsection{Chemometric analysis}

Principal Component Analysis (PCA) was applied on obtained data in order to get a better overview of the similarities between convective dried, vacuum dried and lyophilised stone fruit based on their physical, chemical and biological properties. Multivariate statistical approach i.e. PCA, was applied in order to differentiate samples dried with different drying techniques and also to find correlations between investigated physical, chemical and biological parameters. Therefore, physical parameters used for PCA were MC, $\mathrm{a}_{\mathrm{w}}, \Delta \mathrm{E}$, texture, chemical parameters were TPC, TFC, TMAC, while biological parameter was antioxidant capacity.

Figure 4. Bi-plot distribution of PC1 and PC2 (a) and PC1 and PC3 (b) for grouping investigated physical, chemical and biological parameters.

Figure 5. Score plot of PC1 and PC2 for grouping fresh, convective dried, vacuum dried and lyophilised samples with prominent sour cherry (a), sweet cherry (b), apricot (c), plum (d) and peach (e) samples.

PCA was carried out in order to reduce the number of dimensions of the complex system with 14 grouping variables. It could be seen that the PC1 and PC2 accounted for $65.02 \%$ (Figure 4.a), while PC2 and PC3 accounted 57.45\% (Figure 4.b) of the total variance of the model. These first three Principal Components (PC) accounted for $76.6 \%$ of the total variance of the model. PC1 was negatively correlated with all grouping parameters except MC, $\mathrm{a}_{\mathrm{w}}$ and springiness. On the other hand, PC2 was negatively correlated with all investigated physical parameters and positively correlated with all texture analysis except springiness and $\Delta \mathrm{E}$. Accordingly, PC3 was negatively correlated with shear force, cohesiveness, $\triangle \mathrm{E}$ and TMAC 
while it positively correlated with penetration force, hardness, chewiness, TFC and all antioxidative tests.

The distribution of the samples was significantly influenced by the type of both fruit and drying techniques, since the following three groups: fresh, convective dried, vacuum dried and lyophilised samples of the each type of fruit could be grouped together (Figure 5). Numbering of dried samples is presented in Table 2, while fresh samples were numbered as SCF, SCEB, SCL, SCSH, AB, ANS4, PTT, PAS, PL and PFT from 1 to 10, respectively. The most clear differences of these three groups could be seen in dried sour cherry, sweet cherry and apricot samples (Figure 5.a,b,c), while group of fresh samples clearly differentiated from other groups in all types of investigated stone fruit. Accordingly, groups of fresh samples were characterized by the high values of both $\mathrm{MC}$ and $\mathrm{a}_{\mathrm{w}}$, which could be expected since these two parameters are in direct correlation. Based on these grouping of fresh samples, it was also expected that groups of convective dried fruit were in opposite upper left quadrant for sour cherry (Figure 5.a), sweet cherry (Figure 5.b) and apricot (Figure 5.c). However, groups of plum (Figure 5.d) and peach (Figure 5.e) convective dried samples were both in left and right opposite upper quadrant. It could be seen that groups of convective dried sour and sweet cherries as well as apricot samples were characterized by the highest values of $\Delta \mathrm{E}$ and all texture analyses, except springiness. The clearest group of vacuum dried and lyophilised samples was obtained in sour cherry samples (Figure 5.a) in down left quadrant, opposite of groups of fresh and convective samples. Group of vacuum dried and lyophilised samples in other fruit samples was randomised and it differentiated less clearly compared to sour cherry vacuum dried and lyophilised samples group (Figure 5.b,c,d,e).

\section{Conclusions}

Characterization of physical, chemical and biological properties of convective dried, vacuum dried and lyophilised stone fruit, as well as analysing and structuring the data sets by principal component analysis (PCA) were obtained in this paper.

The lowest moisture content (6.54\%), water activity (0.255) and total colour change (3.15) of all investigated dried samples were observed in lyophilised plum Toptaste; lyophilised sour 
cherry Erdi Botermo and lyophilised apricot NS4; convective dried sour cherry Feketicka, respectively.

Based on the results obtained for texture analyses of all dried samples, it could be concluded that in dried apricot NS4 samples applied drying techniques significantly influenced $(p<$ 0.05) the obtained shear force, hardness, springiness and cohesiveness. On the other hand, properties of variety of sweet cherry did not significantly influence $(p<0.05)$ shear force, penetration force, hardness, springiness and chewiness during vacuum drying.

The highest total phenolic and flavonoid content of all dried samples were obtained in the vacuum dried sour cherry Feketicka sample, while the highest total monomeric anthocyanin content was observed in vacuum dried plum Toptaste sample. Drying techniques significantly influenced $(p<0.05)$ the total phenolic, flavonoid and monomeric anthocyanin content in dried sour cherry Feketicka, sweet cherry Lapins, sweet cherry Sweet Heart and plum Toptase samples.

Based on the results obtained with DPPH and ABTS antioxidant tests, the convective dried plum Toptase sample possesses the highest antioxidant capacity, while FRAP test showed that the sample with the highest antioxidant capacity was vacuum dried sour cherry Feketicka. Drying techniques significantly influenced $(p<0.05)$ the antioxidant capacity of dried sour cherry Feketicka, plum Anna Spath and peach Lela samples, based on results obtained from all three antioxidative tests.

The first three Principal Components (PC) accounted for $76.6 \%$ of the total variance of the model. The most apparent differentiations of the groups of fresh; convective dried; and vacuum dried and lyophilised samples of the each type of investigated stone fruit were obtained in fresh and dried sour cherry Feketicka and Erdi Botermo samples.

\section{Acknowledgments}

This work was supported by the Ministry of Education, Science and Technological Development of the Republic of Serbia [Project 451-03-68/2020-14/ 200134]. 
The authors would like to thank Professor Andreja Rajković, Faculty of Bioscience engineering, Ghent University, for cooperation in the framework of Erasmus+ programme for academic staff mobility, Key Action 1.

\section{References}

Abhay, S. M., Hii, C. L., Law, C. L., Suzannah, S., \& Djaeni, M. (2016). Effect of hot-air drying temperature on the polyphenol content and the sensory properties of cocoa beans. International Food Research Journal, 23.

Aghbashlo, M., Kianmehr, M. H., \& Hassan-Beygi, S. R. (2010). Drying and rehydration characteristics of sour cherry (Prunus cerasus L.). Journal of Food Processing and Preservation, 34, 351-365. doi: https://doi.org/10.1111/j.1745-4549.2008.00310.x

Assefa, A. D., \& Keum, Y. S. (2017). Effect of extraction solvent and various drying methods on polyphenol content and antioxidant activities of yuzu (Citrus junos Sieb ex Tanaka). Journal of Food Measurement and Characterization, 11, 576-585.

Benzie, I. F., \& Strain, J. J. (1996). The ferric reducing ability of plasma (FRAP) as a measure of "antioxidant power": the FRAP assay. Analytical Biochemistry, 239, 70-76. doi: https://doi.org/10.1006/abio.1996.0292

Beuchat, L. R., Komitopoulou, E., Beckers, H., Betts, R. P., Bourdichon, F., Fanning, S., \& Ter Kuile, B. H. (2013). Low-water activity foods: increased concern as vehicles of foodborne pathogens. Journal of Food Protection, 76. 150-172. doi: https://doi.org/10.4315/0362-028X.JFP-12-211

Bianchi, T., Guerrero, L., Gratacós-Cubarsí, M., Claret, A., Argyris, J., Garcia-Mas, J., \& Hortós M. (2016). Textural properties of different melon (Cucumis melo L.) fruit types: Sensory and physical-chemical evaluation. Scientia Horticulturae, 201, 46-56. doi: https://doi.org/10.1016/j.scienta.2016.01.028

Bourdoux, S., Li, D., Rajkovic, A., Devlieghere, F., \& Uyttendaele, M. (2016). Performance of Drying Technologies to Ensure Microbial Safety of Dried Fruits and Vegetables. Comprehensive Reviews in Food Science and Food Safety, 15, 1056-1066. doi: https://doi.org/10.1111/1541-4337.12224 
Bourne, M. (1978). Texture profile analysis. Food Technology, 32, 62-66.

Brand-Williams, W., Cuvelier, M. E., \& Berset, C. (1995). Use of a free radical method to evaluate antioxidant activity. LWT - Food Science and Technology, 28, 25-30. doi: https://doi.org/10.1016/S0023-6438(95)80008-5

Celik, O. F., Demirkol, M., Durmus, Y., \& Tarakci, Z. (2020). Effects of drying method on the phenolics content and antioxidant activities of cherry laurel (Prunus laurocerasus L.). Journal of Food Measurement and Characterization, 14, 48-54.

Chen, Z. G., Guo, X. Y., \& Wu, T. (2016). A novel dehydration technique for carrot slices implementing ultrasound and vacuum drying methods. Ultrasonics Sonochemistry, 30, 2834. doi: https://doi.org/10.1016/j.ultsonch.2015.11.026

Decleer, M., Rajkovic, A., Sas, B., Madder, A., \& De Saeger, S. (2016). Development and validation of ultra-high-performance liquid chromatography-tandem mass spectrometry methods for the simultaneous determination of beauvericin, enniatins (A, A1, B, B1) and cereulide in maize, wheat, pasta and rice. Journal of Chromatography A, 1472, 35-43. doi: https://doi.org/10.1016/j.chroma.2016.10.003

Doymaz, İ., \& İsmail, O. (2011). Drying characteristics of sweet cherry. Food and Bioproducts Processing, 89, 31-38. doi: https://doi.org/10.1016/j.fbp.2010.03.006

Doymaz, I. (2014). Suitability of thin-layer drying models for infrared drying of peach slices. Journal of food processing and preservation, 38, 2232-2239. doi: https://doi.org/10.1111/jfpp.12277

Drusch, S., \& Ragab, W. (2003). Mycotoxins in fruits, fruit juices, and dried fruits. Journal of Food Protection, 66, 1514-1527. doi: https://doi.org/10.4315/0362-028X-66.8.1514

Esti, M., Cinquanta, L., Sinesio, F., Moneta, E., \& Di Matteo, M. (2002). Physicochemical and sensory fruit characteristics of two sweet cherry cultivars after cool storage. Food Chemistry, 76, 399-405. doi: https://doi.org/10.1016/S0308-8146(01)00231-X

Garofulić, I. E., Dragović-Uzelac, V., Jambrak, A. R., \& Jukić, M. (2013). The effect of microwave assisted extraction on the isolation of anthocyanins and phenolic acids from sour cherry Marasca (Prunus cerasus var. Marasca). Journal of Food Engineering, 117, 437-442. doi: https://doi.org/10.1016/j.jfoodeng.2012.12.043 
Goyal, R. K., Kingsly, A. R. P., Manikantan, M. R., \& Ilyas, S. M. (2007). Mathematical modelling of thin layer drying kinetics of plum in a tunnel dryer. Journal of Food Engineering, 79, 176-180. doi: https://doi.org/10.1016/j.jfoodeng.2006.01.041

Hooshmand, S., \& Arjmandi, B. H. (2009). Dried plum, an emerging functional food that may effectively improve bone health. Ageing research Reviews, 8, 122-127. doi: https://doi.org/10.1016/j.arr.2009.01.002

Igual, M., García-Martínez, E., Martín-Esparza, M. E., \& Martínez-Navarrete, N. (2012). Effect of processing on the drying kinetics and functional value of dried apricot. Food Research International, 47, 284-290. doi: https://doi.org/10.1016/j.foodres.2011.07.019

Ihns, R., Diamante, L. M., Savage, G. P., \& Vanhanen, L. (2011). Effect of temperature on the drying characteristics, colour, antioxidant and beta-carotene contents of two apricot varieties. International Journal of Food Science \& Technology, 46, 275-283. doi: https://doi.org/10.1111/j.1365-2621.2010.02506.x

Kwon, G. M., Kim, J. W., \& Youn, K. (2013). Effect of different pre-treatments on the physicochemical and antioxidant activities of cold-vacuum dried peaches. Korean Journal of Food Science and Technology, 45, 466-472. doi: https://doi.org/10.9721/KJFST.2013.45.4.466

Larrosa, A. P., Cadaval, T. R., \& Pinto, L. A. (2015). Influence of drying methods on the characteristics of a vegetable paste formulated by linear programming maximizing antioxidant activity. LWT-Food Science and Technology, 60, 178-185. doi: https://doi.org/10.1016/j.lwt.2014.08.003

Leong, S. Y., \& Oey, I. (2012). Effects of processing on anthocyanins, carotenoids and vitamin C in summer fruits and vegetables. Food Chemistry, 133, 1577-1587. doi: https://doi.org/10.1016/j.foodchem.2012.02.052

Lopez, A., Pique, M. T., Boatella, J., Parcerisa, J., Romero, A., Ferrá, A., \& Garcí, J. (1997). Influence of drying conditions on the hazelnut quality. II. Enzymatic activity. Drying Technology, 15, 979-988. doi: https://doi.org/10.1080/07373939708917272

MacDonald, S., Wilson, P., Barnes, K., Damant, A., Massey, R., Mortby, E., Shepherd, M. J. (1999). Ochratoxin A in dried vine fruit: method development and survey. Food Additives \& Contaminants, 16, 253-260. doi: https://doi.org/10.1080/026520399284019 
Madrau, M. A., Piscopo, A., Sanguinetti, A. M., Del Caro, A., Poiana, M., Romeo, F. V., \& Piga, A. (2009). Effect of drying temperature on polyphenolic content and antioxidant activity of apricots. European Food Research and Technology, 228, 441. doi: $10.1007 / \mathrm{s} 00217-008-0951-6$

Maria do Socorro, M. R., Alves, R. E., de Brito, E. S., Pérez-Jiménez, J., Saura-Calixto, F., \& Mancini-Filho, J. (2010). Bioactive compounds and antioxidant capacities of 18 nontraditional tropical fruits from Brazil. Food Chemistry, 121, 996-1002. doi: https://doi.org/10.1016/j.foodchem.2010.01.037

Mujumdar, A. S., \& Beke, J. (2003). Grain drying: Basic principles, in Handbook of postharvest technology: Cereals, fruits, vegetables, tea, and spices (eds Chakraverty, A., Mujumdar, A. S., Raghavan, G. S. V., Ramaswamy, H. S.). Marcel Dekker, New York, USA, pp. 119-139.

Mulet, A., Cárcel, J. A., Sanjuan, N., Bon, J. (2003). New food drying technologies-Use of ultrasound. Food Science and Technology International, 9, 215-221. doi: https://doi.org/10.1177/1082013203034641

Oancea, S., Grosu, C., Ketney, O., \& Stoia, M. (2013). Conventional and ultrasound-assisted extraction of anthocyanins from blackberry and sweet cherry cultivars. Acta Chimica Slovenica, 60, 383-389.

Ouaabou, R., Nabil, B., Ouhammou, M., Idlimam, A., Lamharrar, A., Ennahli, S., Hanine, H., \& Mahrouz, M. (2020). Impact of solar drying process on drying kinetics, and on bioactive profile of Moroccan sweet cherry. Renewable Energy, 151, 908-918.

Papoutsis, K., Vuong, Q. V., Golding, J. B., Hasperué, J. H., Pristijono, P., Bowyer, M. C., Scarlett, M. C., \& Stathopoulos, C. E. (2018). Pretreatment of citrus by-products affects polyphenol recovery: A review. Food Reviews International, 34, 770-795.

Pei, F., Yang, W. J., Shi, Y., Sun, Y., Mariga, A. M., Zhao, L. Y. \& Hu, Q. H. (2014). Comparison of freeze-drying with three different combinations of drying methods and their influence on colour, texture, microstructure and nutrient retention of button mushroom (Agaricus bisporus) slices. Food and Bioprocess Technology, 7, 702-710. doi: https://doi.org/10.1007/s11947-013-1058-z 
Popović, B. M., Štajner, D., Kevrešan, S., \& Bijelić, S. (2012). Antioxidant capacity of cornelian cherry (Cornus mas L.)-Comparison between permanganate reducing antioxidant capacity and other antioxidant methods. Food Chemistry, 134, 734-741. doi: https://doi.org/10.1016/j.foodchem.2012.02.170

Pu, Y. Y., \& Sun, D. W. (2016). Prediction of moisture content uniformity of microwavevacuum dried mangoes as affected by different shapes using NIR hyperspectral imaging. Innovative Food Science \& Emerging Technologies, 33, 348-356. doi: https://doi.org/10.1016/j.ifset.2015.11.003

Rangkadilok, N., Sitthimonchai, S., Worasuttayangkurn, L., Mahidol, C., Ruchirawat, M., \& Satayavivad, J. (2007). Evaluation of free radical scavenging and antityrosinase activities of standardized longan fruit extract. Food and Chemical Toxicology, 45, 328-336. doi: https://doi.org/10.1016/j.fct.2006.08.022

Re, R., Pellegrini, N., Proteggente, A., Pannala, A., Yang, M., \& Rice-Evans, C. (1999). Antioxidant activity applying an improved ABTS radical cation decolorization assay. Free Radical Biology and Medicine, 26, 1231-1237. doi: https://doi.org/10.1016/S08915849(98)00315-3

Serradilla, M. J., Lozano, M., Bernalte, M. J., Ayuso, M. C., López-Corrales, M., \& González-Gómez D. (2011). Physicochemical and bioactive properties evolution during ripening of 'Ambrunés' sweet cherry cultivar. LWT-Food Science and Technology, 44, 199205. doi: https://doi.org/10.1016/j.lwt.2010.05.036

Sultana, B., Anwar, F., Ashraf, M., \& Saari, N. (2012). Effect of drying techniques on the total phenolic contents and antioxidant activity of selected fruits. Journal of Medicinal Plants Research, 6, 161-167. doi: https://doi.org/10.5897/JMPR11.916

Šumić, Z., Tepić, A., Vidović, S., Jokić, S., \& Malbaša, R. (2013). Optimization of frozen sour cherries vacuum drying process. Food Chemistry, 136, 55-63. doi: https://doi.org/10.1016/j.foodchem.2012.07.102

Šumić, Z., Vakula, A., Tepić, A., Čakarević, J., Vitas, J., \& Pavlić, B. (2016). Modelling and optimization of red currants vacuum drying process by response surface methodology (RSM). Food Chemistry 203, 465-475. doi: https://doi.org/10.1016/j.foodchem.2016.02.109 
Szczesniak, A. S. (2002). Texture is a sensory property. Food Quality and Preference, 13, 215-225. doi: https://doi.org/10.1016/S0950-3293(01)00039-8

Tepić Horecki, A., Vakula, A., Pavlić, B., Jokanović, M., Malbaša, R., Vitas, J., Jaćimović, V., \& Šumić, Z. (2018). Comparative drying of cornelian cherries: Kinetics modeling and physico- chemical properties. Journal of Food Processing and Preservation, 42, e13562. doi: https://doi.org/10.1111/jfpp.13562

Toğrul, İ. T., \& Pehlivan, D. (2003). Modelling of drying kinetics of single apricot. Journal of Food Engineering, 58, 23-32. doi: https://doi.org/10.1016/S0260-8774(02)00329-1

Tolosa, J., Font, G., Mañes, J., \& Ferrer, E. (2013). Nuts and dried fruits: natural occurrence of emerging Fusarium mycotoxins. Food Control, 33, 215-220. doi: https://doi.org/10.1016/j.foodcont.2013.02.023

Tomás-Barberán, F. A., Gil, M. I., Cremin, P., Waterhouse, A. L., Hess-Pierce, B., \& Kader, A. A. (2001). HPLC-DAD- ESIMS analysis of phenolic compounds in nectarines, peaches, and plums. Journal of Agricultural and Food Chemistry, 49, 4748-4760. doi: https://doi.org/10.1021/jf0104681

Vakula, A., Šumić, Z., Zeković, Z., Tepić Horecki, A., \& Pavlić, B. (2019). Screening, influence analysis and optimization of ultrasound- assisted extraction parameters of cornelian cherries (Cornus mas L.). Journal of Food Processing and Preservation, 43, e14226. doi: https://doi.org/10.1111/jfpp.14226

Vargas, E. F. D., Jablonski, A., Flôres, S. H., \& Rios, A. D. O. (2017). Waste from peach (Prunus persica) processing used for optimisation of carotenoids ethanolic extraction. International Journal of Food Science \& Technology, 52, 757-762. doi: https://doi.org/10.1111/ijfs. 13332

Wang, M., Jiang, N., Wang, Y., Jiang, D., \& Feng, X. (2017). Characterization of phenolic compounds from early and late ripening sweet cherries and their antioxidant and antifungal activities. Journal of Agricultural and Food Chemistry, 65, 5413-5420. doi: https://doi.org/10.1021/acs.jafc.7b01409

Wills, R. B., Scriven, F. M., \& Greenfield, H. (1983) Nutrient composition of stone fruit (Prunus spp.) cultivars: apricot, cherry, nectarine, peach and plum. Journal of the Science of Food and Agriculture, 34, 1383-1389. doi: https://doi.org/10.1002/jsfa.2740341211 
Wojdyło, A., Figiel, A., Lech, K., Nowicka, P., \& Oszmiański, J. (2014). Effect of convective and vacuum-microwave drying on the bioactive compounds, color, and antioxidant capacity of sour cherries. Food and Bioprocess Technology, 7, 829-841. doi: https://doi.org/10.1007/s11947-013-1130-8

Xie, L., Mujumdar, A. S., Fang, X. M., Wang, J., Dai, J. W., Du, Z. L., Xiao, H. W., Liu, Y., \& Gao, Z. J. (2017). Far-infrared radiation heating assisted pulsed vacuum drying (FIR-PVD) of Wolfberry (Lycium barbarum L.): effects on drying kinetics and quality attributes. Food and Bioproducts Processing, 102, 320-331. doi: https://doi.org/10.1016/j.fbp.2017.01.012

Zaghdoudi, K., Pontvianne, S., Framboisier, X., Achard, M., Kudaibergenova, R., AyadiTrabelsi, M., Kalthoum-cherif, J., Vanderesse, R., Frochot, C., \& Guiavarc'h, Y. (2015). Accelerated solvent extraction of carotenoids from: Tunisian Kaki (Diospyros kaki L.), peach (Prunus persica L.) and apricot (Prunus armeniaca L.). Food chemistry, 184, 131-139. doi: https://doi.org/10.1016/j.foodchem.2015.03.072 
Figure 1. Experimental design-flow chart.

Figure 2. Total phenolic (a), flavonoid (b) and monomeric anthocyanin (c) content observed in raw, convective dried, vacuum dried and lyophilised samples.

Figure 3. Antioxidant capacity of raw, convective dried, vacuum dried and lyophilised samples obtained by FRAP (a), DPPH (b) and ABTS (c) test.

Figure 4. Bi-plot distribution of PC1 and PC2 (a) and PC1 and PC3 (b) for grouping investigated physical, chemical and biological parameters.

Figure 5. Score plot of PC1 and PC2 for grouping raw, convective dried, vacuum dried and lyophilised samples with prominent sour cherry (a), sweet cherry (b), apricot (c), plum (d) and peach (e) samples. 
Table 1. Fresh and dried stone fruit-abbreviations

\begin{tabular}{|c|c|c|c|c|}
\hline Number & Fruit type & Fruit variety & State & Abbreviation \\
\hline 1 & \multirow{2}{*}{ Sour cherry } & Feketicka & \multirow{10}{*}{ Fresh } & SCF-F \\
\hline 2 & & Erdi Botermo & & SCEB-F \\
\hline 3 & \multirow{2}{*}{ Sweet cherry } & Lapins & & SCL-F \\
\hline 4 & & Sweet Heart & & SCSH-F \\
\hline 5 & \multirow{2}{*}{ Apricot } & Buda & & AB-F \\
\hline 6 & & NS4 & & ANS4-F \\
\hline 7 & \multirow{2}{*}{ Plum } & Anna Spath & & PAS-F \\
\hline 8 & & Toptaste & & PTT-F \\
\hline 9 & \multirow{2}{*}{ Peach } & Lela & & PL-F \\
\hline 10 & & Fairtime & & PFT-F \\
\hline 11 & \multirow{2}{*}{ Sour cherry } & Feketicka & \multirow{10}{*}{ Convective dried } & SCF-C \\
\hline 12 & & Erdi Botermo & & SCEB-C \\
\hline 13 & \multirow{2}{*}{ Sweet cherry } & Lapins & & SCL-C \\
\hline 14 & & Sweet Heart & & SCSH-C \\
\hline 15 & \multirow{2}{*}{ Apricot } & Buda & & $\mathrm{AB}-\mathrm{C}$ \\
\hline 16 & & NS4 & & ANS4-C \\
\hline 17 & \multirow{2}{*}{ Plum } & Anna Spath & & PAS-C \\
\hline 18 & & Toptaste & & PTT-C \\
\hline 19 & \multirow{2}{*}{ Peach } & Lela & & PL-C \\
\hline 20 & & Fairtime & & PFT-C \\
\hline 21 & \multirow{2}{*}{ Sour cherry } & Feketicka & \multirow{10}{*}{ Vacuum dried } & SCF-V \\
\hline 22 & & Erdi Botermo & & SCEB-V \\
\hline 23 & \multirow{2}{*}{ Sweet cherry } & Lapins & & SCL-V \\
\hline 24 & & Sweet Heart & & SCSH-V \\
\hline 25 & \multirow{2}{*}{ Apricot } & Buda & & AB-V \\
\hline 26 & & NS4 & & ANS4-V \\
\hline 27 & \multirow{2}{*}{ Plum } & Anna Spath & & PAS-V \\
\hline 28 & & Toptaste & & PTT-V \\
\hline 29 & \multirow{2}{*}{ Peach } & Lela & & PL-V \\
\hline 30 & & Fairtime & & PFT-V \\
\hline
\end{tabular}




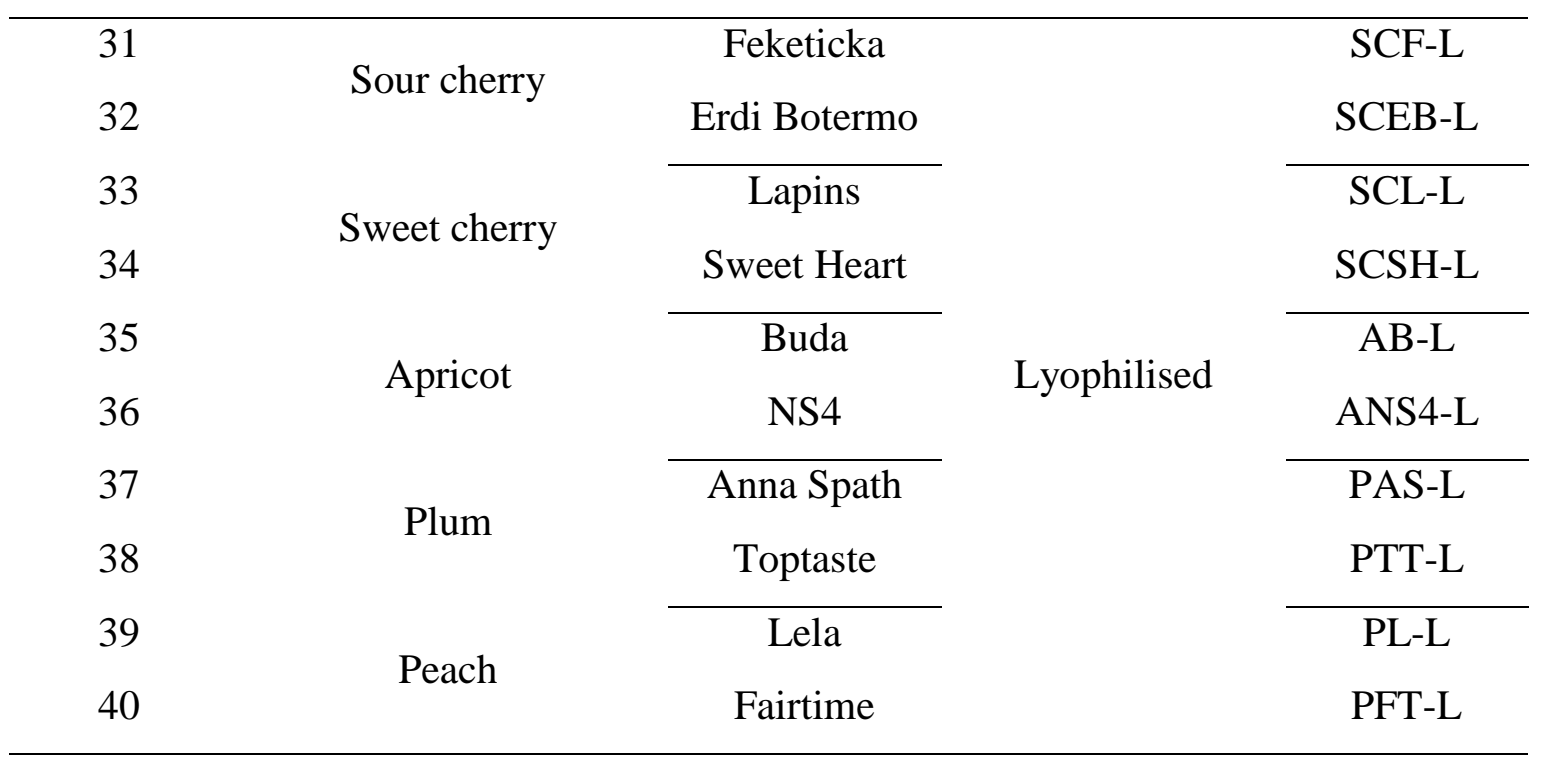


Table 2. Conditions of convective drying, vacuum drying and lyophilisation.

\begin{tabular}{|c|c|c|c|c|c|}
\hline Number & Fruit & Sample & $\begin{array}{l}\text { Pressure } \\
\text { [mbar] }\end{array}$ & $\begin{array}{l}\text { Temperature } \\
{\left[{ }^{\circ} \mathrm{C}\right]}\end{array}$ & $\begin{array}{l}\text { Drying time } \\
{[\mathrm{h}]}\end{array}$ \\
\hline 11 & sour cherry Feketicka & SCF-C & 1000 & 78 & 24 \\
\hline 12 & sour cherry Erdi Botermo & SCEB-C & 1000 & 78 & 24 \\
\hline 13 & sweet cherry Lapins & SCL-C & 1000 & 78 & 25 \\
\hline 14 & sweet cherry Sweet Heart & SCSH-C & 1000 & 78 & 23 \\
\hline 15 & apricot Buda & $\mathrm{AB}-\mathrm{C}$ & 1000 & 78 & 17 \\
\hline 16 & apricot NS4 & ANS4-C & 1000 & 78 & 18 \\
\hline 17 & plum Anna Spath & PAS-C & 1000 & 78 & 24 \\
\hline 18 & plum Toptaste & PTT-C & 1000 & 78 & 24 \\
\hline 19 & peach Lela & PL-C & 1000 & 78 & 22 \\
\hline 20 & peach Fairtime & PFT-C & 1000 & 78 & 21 \\
\hline 21 & sour cherry Feketicka & SCF-V & 20 & 60 & 11 \\
\hline 22 & sour cherry Erdi Botermo & SCEB-V & 20 & 60 & 11 \\
\hline 23 & sweet cherry Lapins & SCL-V & 20 & 60 & 13 \\
\hline 24 & sweet cherries Sweet Heart & SCSH-V & 20 & 60 & 16 \\
\hline 25 & apricot Buda & AB-V & 20 & 60 & 19 \\
\hline 26 & apricot NS4 & ANS4-V & 20 & 60 & 19 \\
\hline 27 & plum Anna Spath & PAS-V & 20 & 60 & 29 \\
\hline 28 & plum Toptaste & PTT-V & 20 & 60 & 28 \\
\hline 29 & peach Lela & PL-V & 20 & 60 & 27 \\
\hline 30 & peach Fairtime & PFT-V & 20 & 60 & 27 \\
\hline 31 & sour cherry Feketicka & SCF-L & 0.01 & -30 & 72 \\
\hline 32 & sour cherry Erdi Botermo & SCEB-L & 0.01 & -30 & 72 \\
\hline 33 & sweet cherry Lapins & SCL-L & 0.01 & -30 & 72 \\
\hline 34 & sweet cherries Sweet Heart & SCSH-L & 0.01 & -30 & 72 \\
\hline 35 & apricot Buda & AB-L & 0.01 & -30 & 72 \\
\hline 36 & apricot NS4 & ANS4-L & 0.01 & -30 & 72 \\
\hline 37 & plum Anna Spath & PAS-L & 0.01 & -30 & 72 \\
\hline 38 & plum Toptaste & PTT-L & 0.01 & -30 & 72 \\
\hline 39 & peach Lela & PL-L & 0.01 & -30 & 72 \\
\hline 40 & peach Fairtime & PFT-L & 0.01 & -30 & 72 \\
\hline
\end{tabular}


Table 3. Experimentally obtained values of $M C, \mathrm{a}_{\mathrm{w}}$ and $\Delta \mathrm{E}$ of dried samples.

\begin{tabular}{|c|c|c|c|c|c|c|}
\hline Analyses & $\mathrm{MC}(\%)$ & & $a_{w}$ & & $\Delta \mathrm{E}$ & \\
\hline Sample & SCF & SCEB & SCF & SCEB & SCF & SCEB \\
\hline SCF-F/SCEB-F & $83.37 \pm 0.06^{\mathrm{A}, \mathrm{b}}$ & $86.64 \pm 0.36^{\mathrm{A}, \mathrm{a}}$ & $0.929 \pm 0.007^{\mathrm{A}, \mathrm{a}}$ & $0.936 \pm 0.001^{\mathrm{A}, \mathrm{a}}$ & $0.00^{*}$ & $0.00^{*}$ \\
\hline SCF-C/SCEB-C & $3.41 \pm 0.17^{\mathrm{C}, \mathrm{a}}$ & $11.20 \pm 0.51^{\mathrm{D}, \mathrm{b}}$ & $0.278 \pm 0.004^{\mathrm{D}, \mathrm{b}}$ & $0.350 \pm 0.000^{\mathrm{C}, \mathrm{a}}$ & $3.15 \pm 0.58^{\mathrm{B}, \mathrm{a}}$ & $4.73 \pm 1.70^{\mathrm{B}, \mathrm{a}}$ \\
\hline SCF-V/SCEB-V & $15.60 \pm 0.88^{\mathrm{B}, \mathrm{b}}$ & $21.29 \pm 0.76^{\mathrm{B}, \mathrm{a}}$ & $0.376 \pm 0.003^{\mathrm{B}, \mathrm{b}}$ & $0.540 \pm 0.003^{\mathrm{B}, \mathrm{a}}$ & $23.44 \pm 5.28^{\mathrm{A}, \mathrm{a}}$ & $7.83 \pm 2.26^{\mathrm{B}, \mathrm{b}}$ \\
\hline SCF-L/SCEB-L & $14.71 \pm 0.15^{\mathrm{B}, \mathrm{b}}$ & $15.11 \pm 0.10^{\mathrm{C}, \mathrm{a}}$ & $0.309 \pm 0.006^{\mathrm{C}, \mathrm{a}}$ & $0.255 \pm 0.000^{\mathrm{D}, \mathrm{b}}$ & $27.52 \pm 4.99^{\mathrm{A}, \mathrm{a}}$ & $26.80 \pm 4.93^{\mathrm{A}, \mathrm{a}}$ \\
\hline Sample & SCL & SCSH & SCL & SCSH & SCL & SCSH \\
\hline SCL-F/SCSH-F & $83.17 \pm 0.17^{\mathrm{A}, \mathrm{a}}$ & $82.00 \pm 0.03^{\mathrm{A}, \mathrm{b}}$ & $0.949 \pm 0.003^{\mathrm{A}, \mathrm{a}}$ & $0.939 \pm 0.003^{\mathrm{A}, \mathrm{a}}$ & $0.00^{*}$ & $0.00^{*}$ \\
\hline SCL-C/SCSH-C & $9.05 \pm 0.36^{\mathrm{D}, \mathrm{a}}$ & $9.12 \pm 0.004^{\mathrm{C}, \mathrm{a}}$ & $0.406 \pm 0.001^{\mathrm{C}, \mathrm{a}}$ & $0.349 \pm 0.003^{\mathrm{C}, \mathrm{b}}$ & $23.17 \pm 0.14^{\mathrm{B}, \mathrm{a}}$ & $21.06 \pm 1.74^{\mathrm{A}, \mathrm{b}}$ \\
\hline SCL-V/SCSH-V & $15.36 \pm 0.30^{\mathrm{B}, \mathrm{a}}$ & $14.72 \pm 0.24^{\mathrm{B}, \mathrm{b}}$ & $0.465 \pm 0.001^{\mathrm{B}, \mathrm{a}}$ & $0.419 \pm 0.003^{\mathrm{B}, \mathrm{b}}$ & $17.93 \pm 1.44^{\mathrm{B}, \mathrm{a}}$ & $15.90 \pm 5.75^{\mathrm{AB}, \mathrm{a}}$ \\
\hline SCL-L/SCSH-L & $12.05 \pm 0.05^{\mathrm{C}, \mathrm{b}}$ & $14.48 \pm 0.02^{\mathrm{B}, \mathrm{a}}$ & $0.292 \pm 0.000^{\mathrm{D}, \mathrm{a}}$ & $0.268 \pm 0.004^{\mathrm{D}, \mathrm{b}}$ & $29.07 \pm 5.46^{\mathrm{A}, \mathrm{a}}$ & $11.07 \pm 6.32^{\mathrm{B}, \mathrm{b}}$ \\
\hline Sample & $\mathrm{AB}$ & ANS4 & $\mathrm{AB}$ & ANS4 & $\mathrm{AB}$ & ANS4 \\
\hline AB-F/ANS4-F & $87.77 \pm 0.16^{\mathrm{A}, \mathrm{b}}$ & $88.77 \pm 0.08^{\mathrm{A}, \mathrm{a}}$ & $0.903 \pm 0.003^{\mathrm{A}, \mathrm{b}}$ & $0.948 \pm 0.006^{\mathrm{A}, \mathrm{a}}$ & $0.00 *$ & $0.00 *$ \\
\hline AB-C/ANS4-C & $17.11 \pm 0.67^{\mathrm{B}, \mathrm{a}}$ & $14.15 \pm 0.98^{\mathrm{B}, \mathrm{b}}$ & $0.368 \pm 0.001^{\mathrm{D}, \mathrm{b}}$ & $0.411 \pm 0.001^{\mathrm{C}, \mathrm{a}}$ & $36.21 \pm 3.26^{\mathrm{B}, \mathrm{b}}$ & $47.76 \pm 1.97^{\mathrm{A}, \mathrm{a}}$ \\
\hline AB-V/ANS4-V & $16.23 \pm 0.39^{\mathrm{B}, \mathrm{a}}$ & $14.36 \pm 0.24^{\mathrm{B}, \mathrm{b}}$ & $0.670 \pm 0.001^{\mathrm{B}, \mathrm{a}}$ & $0.544 \pm 0.000^{\mathrm{B}, \mathrm{b}}$ & $13.67 \pm 1.84^{\mathrm{C}, \mathrm{b}}$ & $18.28 \pm 1.50^{\mathrm{B}, \mathrm{a}}$ \\
\hline AB-L/ANS4-L & $16.55 \pm 0.22^{\mathrm{B}, \mathrm{a}}$ & $7.66 \pm 0.44^{\mathrm{C}, \mathrm{b}}$ & $0.425 \pm 0.000^{\mathrm{C}, \mathrm{a}}$ & $0.255 \pm 0.001^{\mathrm{D}, \mathrm{b}}$ & $43.50 \pm 1.47^{\mathrm{A}, \mathrm{b}}$ & $49.43 \pm 1.85^{\mathrm{A}, \mathrm{a}}$ \\
\hline Sample & PTT & PAS & PTT & PAS & PTT & PAS \\
\hline PTT-F/PAS-F & $77.98 \pm 0.30^{\mathrm{A}, \mathrm{a}}$ & $77.81 \pm 0.12^{\mathrm{A}, \mathrm{a}}$ & $0.975 \pm 0.007^{\mathrm{A}, \mathrm{a}}$ & $0.973 \pm 0.001^{\mathrm{A}, \mathrm{a}}$ & $0.00 *$ & $0.00 *$ \\
\hline PTT-C/PAS-C & $7.99 \pm 0.05^{\mathrm{C}, \mathrm{b}}$ & $13.11 \pm 0.05^{\mathrm{C}, \mathrm{a}}$ & $0.404 \pm 0.001^{\mathrm{C}, \mathrm{a}}$ & $0.395 \pm 0.003^{\mathrm{C}, \mathrm{a}}$ & $4.76 \pm 0.77^{\mathrm{B}, \mathrm{b}}$ & $11.72 \pm 0.52^{\mathrm{A}, \mathrm{a}}$ \\
\hline PTT-V/PAS-V & $19.03 \pm 0.40^{\mathrm{B}, \mathrm{b}}$ & $48.71 \pm 0.19^{\mathrm{B}, \mathrm{a}}$ & $0.564 \pm 0.000^{\mathrm{B}, \mathrm{b}}$ & $0.791 \pm 0.001^{\mathrm{B}, \mathrm{a}}$ & $5.25 \pm 2.06^{\mathrm{B}, \mathrm{a}}$ & $7.22 \pm 1.72^{\mathrm{B}, \mathrm{a}}$ \\
\hline
\end{tabular}




\begin{tabular}{lllllll} 
PTT-L/PAS-L & $6.54 \pm 0.04^{\mathrm{D}, \mathrm{b}}$ & $11.65 \pm 0.13^{\mathrm{D}, \mathrm{a}}$ & $0.256 \pm 0.006^{\mathrm{D}, \mathrm{a}}$ & $0.258 \pm 0.003^{\mathrm{D}, \mathrm{a}}$ & $8.36 \pm 1.57^{\mathrm{A}, \mathrm{a}}$ & $5.76 \pm 3.07^{\mathrm{B}, \mathrm{a}}$ \\
\hline Sample & PL & PFT & PL & PFT & PL & PFT \\
\hline PL-F/PFT-F & $88.23 \pm 0.21^{\mathrm{A}, \mathrm{a}}$ & $87.95 \pm 0.08^{\mathrm{A}, \mathrm{a}}$ & $0.973 \pm 0.001^{\mathrm{A}, \mathrm{b}}$ & $0.988 \pm 0.001^{\mathrm{A}, \mathrm{a}}$ & $0.00^{*}$ & $0.00^{*}$ \\
PL-C/PFT-C & $10.48 \pm 0.02^{\mathrm{C}, \mathrm{b}}$ & $14.96 \pm 0.04^{\mathrm{B}, \mathrm{a}}$ & $0.471 \pm 0.001^{\mathrm{C}, \mathrm{a}}$ & $0.451 \pm 0.003^{\mathrm{B}, \mathrm{b}}$ & $42.91 \pm 3.46^{\mathrm{A}, \mathrm{a}}$ & $34.23 \pm 2.65^{\mathrm{A}, \mathrm{b}}$ \\
PL-V/PFT-V & $12.45 \pm 0.06^{\mathrm{B}, \mathrm{b}}$ & $14.99 \pm 0.24^{\mathrm{B}, \mathrm{a}}$ & $0.522 \pm 0.003^{\mathrm{B}, \mathrm{a}}$ & $0.339 \pm 0.000^{\mathrm{C}, \mathrm{b}}$ & $7.39 \pm 2.65^{\mathrm{C}, \mathrm{b}}$ & $36.92 \pm 3.22^{\mathrm{A}, \mathrm{a}}$ \\
PL-L/PFT-L & $9.14 \pm 0.06^{\mathrm{D}, \mathrm{b}}$ & $11.65 \pm 0.29^{\mathrm{C}, \mathrm{a}}$ & $0.266 \pm 0.000^{\mathrm{D}, \mathrm{b}}$ & $0.287 \pm 0.004^{\mathrm{D}, \mathrm{a}}$ & $22.62 \pm 0.28^{\mathrm{B}, \mathrm{a}}$ & $24.82 \pm 3.13^{\mathrm{B}, \mathrm{a}}$
\end{tabular}

Means that do not share a letter are significantly different $(p<0.05)$

Uppercase letters A, B, C and D - differences between raw, convective dried, vacuum dried and lyophilised samples within one variety of fruit

Lowercase letters $a$ and $b$ - differences between two varieties of the same type of fruit within one drying technique 
Table 4. Experimentally obtained values of dried samples texture.

\begin{tabular}{|c|c|c|c|c|c|c|}
\hline Analyses & Shear force $(\mathrm{g})$ & & Penetration force & & Hardness (g) & \\
\hline Sample & SCF & SCEB & SCF & SCEB & SCF & SCEB \\
\hline SCF-F/SCEB-F & $168.6 \pm 55.3^{\mathrm{C}, \mathrm{b}}$ & $310.5 \pm 151.0^{\mathrm{B}, \mathrm{a}}$ & $92.4 \pm 11.2^{\mathrm{C}, \mathrm{a}}$ & $94.6 \pm 20.1^{\mathrm{D}, \mathrm{a}}$ & $210.2 \pm 65.9^{\mathrm{C}, \mathrm{b}}$ & $401.5 \pm 67.7^{\mathrm{B}, \mathrm{a}}$ \\
\hline SCF-C/SCEB-C & $1602.7 \pm 1085.0^{\mathrm{B}, \mathrm{b}}$ & $2723.5 \pm 906.7^{\mathrm{A}, \mathrm{a}}$ & $>5000.0^{\mathrm{A}}$ & $>5000.0^{\mathrm{A}}$ & $2263.2 \pm 810.2^{\mathrm{A}, \mathrm{b}}$ & $3102.3 \pm 894.5^{\mathrm{A}, \mathrm{a}}$ \\
\hline SCF-V/SCEB-V & $2680.3 \pm 1032.5^{\mathrm{AB}, \mathrm{a}}$ & $988.0 \pm 319.9^{\mathrm{B}, \mathrm{b}}$ & $1730.7 \pm 1030.9^{\mathrm{B}, \mathrm{a}}$ & $664.7 \pm 247.9^{\mathrm{C}, \mathrm{b}}$ & $1129.5 \pm 311.7^{\mathrm{B}, \mathrm{a}}$ & $341.5 \pm 136.5^{\mathrm{B}, \mathrm{b}}$ \\
\hline SCF-L/SCEB-L & $3569.4 \pm 1430.6^{\mathrm{A}, \mathrm{a}}$ & $2867.8 \pm 1242.7^{\mathrm{A}, \mathrm{a}}$ & $1171.6 \pm 398.1^{\mathrm{B}, \mathrm{b}}$ & $1747.8 \pm 549.1^{\mathrm{B}, \mathrm{a}}$ & $654.5 \pm 151.3^{\mathrm{BC}, \mathrm{a}}$ & $673.6 \pm 450.5^{\mathrm{B}, \mathrm{a}}$ \\
\hline Sample & SCL & SCSH & SCL & SCSH & SCL & SCSH \\
\hline SCL-F/SCSH-F & $228.7 \pm 124.4^{\mathrm{B}, \mathrm{a}}$ & $216.3 \pm 72.21^{\mathrm{B}, \mathrm{a}}$ & $135.3 \pm 45.0^{\mathrm{D}, \mathrm{b}}$ & $191.1 \pm 38.2^{\mathrm{D}, \mathrm{a}}$ & $728.6 \pm 124.9^{\mathrm{B}, \mathrm{a}}$ & $810.0 \pm 118.8^{\mathrm{C}, \mathrm{a}}$ \\
\hline SCL-C/SCSH-C & $3194.6 \pm 998.1^{\mathrm{A}, \mathrm{a}}$ & $3372.0 \pm 1853.2^{\mathrm{A}, \mathrm{a}}$ & $>5000.0^{\mathrm{A}}$ & $>5000.0^{\mathrm{A}}$ & $1800.5 \pm 1121.1^{\mathrm{A}, \mathrm{a}}$ & $2237.9 \pm 814.7^{\mathrm{A}, \mathrm{a}}$ \\
\hline SCL-V/SCSH-V & $777.4 \pm 443.1^{\mathrm{B}, \mathrm{a}}$ & $911.0 \pm 159.6^{\mathrm{B}, \mathrm{a}}$ & $675.6 \pm 224.6^{\mathrm{C}, \mathrm{a}}$ & $696.7 \pm 202.0^{\mathrm{C}, \mathrm{a}}$ & $405.9 \pm 144.5^{\mathrm{B}, \mathrm{a}}$ & $396.1 \pm 126.3^{\mathrm{C}, \mathrm{a}}$ \\
\hline SCL-L/SCSH-L & $3718 \pm 1337.7^{\mathrm{A}, \mathrm{a}}$ & $2705.9 \pm 692.6^{\mathrm{A}, \mathrm{b}}$ & $1096.5 \pm 233.1^{\mathrm{B}, \mathrm{a}}$ & $1368.6 \pm 576.2^{\mathrm{B}, \mathrm{a}}$ & $786.8 \pm 235.0^{\mathrm{B}, \mathrm{b}}$ & $1454.8 \pm 340.8^{\mathrm{B}, \mathrm{a}}$ \\
\hline Sample & $\mathrm{AB}$ & ANS4 & $\mathrm{AB}$ & ANS4 & $\mathrm{AB}$ & ANS4 \\
\hline AB-F/ANS4-F & $10.9 \pm 3.10^{\mathrm{C}, \mathrm{a}}$ & $11.2 \pm 4.59^{\mathrm{C}, \mathrm{a}}$ & $351.2 \pm 75.0^{\mathrm{C}, \mathrm{a}}$ & $148.4 \pm 41.2^{\mathrm{C}, \mathrm{b}}$ & $1107.1 \pm 749.7^{\mathrm{AB}, \mathrm{a}}$ & $549.9 \pm 181.5^{\mathrm{C}, \mathrm{b}}$ \\
\hline AB-C/ANS4-C & $1986.2 \pm 1198.6^{\mathrm{A}, \mathrm{b}}$ & $3535.1 \pm 1059.1^{\mathrm{A}, \mathrm{a}}$ & $>5000.0^{\mathrm{A}}$ & $>5000.0^{\mathrm{A}}$ & $1851.3 \pm 1562.7^{\mathrm{A}, \mathrm{a}}$ & $2109.1 \pm 1742.2^{\mathrm{B}, \mathrm{a}}$ \\
\hline AB-V/ANS4-V & $896.1 \pm 595.2^{\mathrm{B}, \mathrm{a}}$ & $1205.5 \pm 291.7^{\mathrm{B}, \mathrm{a}}$ & $884.1 \pm 383.4^{\mathrm{B}, \mathrm{a}}$ & $921.5 \pm 293.8^{\mathrm{B}, \mathrm{a}}$ & $478.9 \pm 19.6^{\mathrm{B}, \mathrm{a}}$ & $422.6 \pm 174.9^{\mathrm{C}, \mathrm{a}}$ \\
\hline AB-L/ANS4-L & $1764.1 \pm 523.9^{\mathrm{A}, \mathrm{a}}$ & $147.4 \pm 76.5^{\mathrm{C}, \mathrm{b}}$ & $1102.7 \pm 533.9^{\mathrm{Baa}}$ & $790.4 \pm 274.9^{\mathrm{B}, \mathrm{a}}$ & $213.9 \pm 151.7^{\mathrm{B}, \mathrm{b}}$ & $3466.0 \pm 1337.5^{\mathrm{A}, \mathrm{a}}$ \\
\hline Sample & PTT & PAS & PTT & PAS & PTT & PAS \\
\hline PTT-F/PAS-F & $442.4 \pm 141.7^{\mathrm{B}, \mathrm{a}}$ & $506.6 \pm 220.4^{\mathrm{B}, \mathrm{a}}$ & $610.1 \pm 130.1^{\mathrm{C,a}}$ & $420.5 \pm 86.4^{\mathrm{C}, \mathrm{b}}$ & $1914.2 \pm 1194.0^{\mathrm{B}, \mathrm{a}}$ & $1731.2 \pm 1215.2^{\mathrm{AB}, \mathrm{a}}$ \\
\hline PTT-C/PAS-C & $3800.7 \pm 938.9^{\mathrm{A}, \mathrm{a}}$ & $2787.3 \pm 1214.9^{\mathrm{A}, \mathrm{b}}$ & $>5000.0^{\mathrm{A}}$ & $>5000.0^{\mathrm{A}}$ & $6377.8 \pm 3549.0^{\mathrm{A}, \mathrm{a}}$ & $3427.3 \pm 2874.7^{\mathrm{A}, \mathrm{b}}$ \\
\hline PTT-V/PAS-V & $332.7 \pm 137.9^{\mathrm{B}, \mathrm{b}}$ & $528.2 \pm 186.1^{\mathrm{B}, \mathrm{a}}$ & $509.3 \pm 163.2^{\mathrm{C}, \mathrm{a}}$ & $611.4 \pm 358.5^{\mathrm{C}, \mathrm{a}}$ & $277.4 \pm 215.3^{\mathrm{B}, \mathrm{a}}$ & $252.4 \pm 128.0^{\mathrm{B}, \mathrm{a}}$ \\
\hline
\end{tabular}




\begin{tabular}{|c|c|c|c|c|c|c|}
\hline PTT-L/PAS-L & $3856.7 \pm 1979.3^{\mathrm{A}, \mathrm{a}}$ & $2827.6 \pm 1425.8^{\mathrm{A}, \mathrm{a}}$ & $2556.7 \pm 844.9^{\mathrm{B}, \mathrm{a}}$ & $2852.9 \pm 713.9^{\mathrm{B}, \mathrm{a}}$ & $960.5 \pm 419.1^{\mathrm{B}, \mathrm{a}}$ & $805.6 \pm 716.9^{\mathrm{B}, \mathrm{a}}$ \\
\hline Sample & PL & PFT & PL & PFT & PL & PFT \\
\hline PL-F/PFT-F & $127.8 \pm 44.3^{\mathrm{B}, \mathrm{a}}$ & $117.6 \pm 36.1^{\mathrm{C}, \mathrm{a}}$ & $480.4 \pm 67.6^{\mathrm{C}, \mathrm{b}}$ & $749.1 \pm 160.2^{\mathrm{C}, \mathrm{a}}$ & $1691.1 \pm 488.8^{\mathrm{A}, \mathrm{a}}$ & $2041.7 \pm 717.1^{\mathrm{B}, \mathrm{a}}$ \\
\hline PL-C/PFT-C & $2734.1 \pm 1226.9^{\mathrm{A}, \mathrm{a}}$ & $2726.6 \pm 1529.9^{\mathrm{A}, \mathrm{a}}$ & $>5000.0^{\mathrm{A}}$ & $>5000.0^{\mathrm{A}}$ & $2604.9 \pm 1711.3^{\mathrm{A}, \mathrm{a}}$ & $719.3 \pm 538.0^{\mathrm{B}, \mathrm{b}}$ \\
\hline PL-V/PFT-V & $2800.1 \pm 1324.5^{\mathrm{A}, \mathrm{a}}$ & $1165.1 \pm 1081.5^{\mathrm{B}, \mathrm{b}}$ & $2710.4 \pm 1603.0^{\mathrm{B}, \mathrm{a}}$ & $1384.0 \pm 757.9^{\mathrm{B}, \mathrm{b}}$ & $2425.0 \pm 1809.8^{\mathrm{A}, \mathrm{a}}$ & $787.6 \pm 660.6^{\mathrm{B}, \mathrm{b}}$ \\
\hline PL-L/PFT-L & $369.2 \pm 189.6^{\mathrm{B}, \mathrm{a}}$ & $424.5 \pm 266.1^{\mathrm{BC}, \mathrm{a}}$ & $1181.3 \pm 370.7^{\mathrm{C}, \mathrm{a}}$ & $825.5 \pm 237.2^{\mathrm{C}, \mathrm{b}}$ & $1062.1 \pm 548.8^{\mathrm{A}, \mathrm{b}}$ & $6153.2 \pm 3015.0^{\mathrm{A}, \mathrm{a}}$ \\
\hline Analyses & Springiness & & Cohesiveness & & Chewiness (g) & \\
\hline Sample & SCF & SCEB & SCF & SCEB & SCF & SCEB \\
\hline SCF-F/SCEB-F & $0.94 \pm 0.24^{\mathrm{A}, \mathrm{a}}$ & $0.79 \pm 0.03^{\mathrm{A}, \mathrm{b}}$ & $0.63 \pm 0.05^{\mathrm{B}, \mathrm{a}}$ & $0.62 \pm 0.04^{\mathrm{A}, \mathrm{a}}$ & $124.2 \pm 45.6^{\mathrm{B}, \mathrm{b}}$ & $196.79 \pm 34.1^{\mathrm{B}, \mathrm{a}}$ \\
\hline SCF-C/SCEB-C & $0.80 \pm 0.06^{\mathrm{A}, \mathrm{a}}$ & $0.75 \pm 0.04^{\mathrm{A}, \mathrm{b}}$ & $0.76 \pm 0.06^{\mathrm{A}, \mathrm{a}}$ & $0.69 \pm 0.04^{\mathrm{AB}, \mathrm{b}}$ & $1390.1 \pm 548.9^{\mathrm{A}, \mathrm{a}}$ & $1637.5 \pm 546.4^{\mathrm{A}, \mathrm{a}}$ \\
\hline SCF-V/SCEB-V & $0.61 \pm 0.05^{\mathrm{B}, \mathrm{b}}$ & $0.70 \pm 0.10^{\mathrm{A}, \mathrm{a}}$ & $0.54 \pm 0.04^{\mathrm{B}, \mathrm{b}}$ & $0.61 \pm 0.04^{\mathrm{A}, \mathrm{a}}$ & $352.7 \pm 67.6^{\mathrm{B}, \mathrm{a}}$ & $143.4 \pm 50.9^{\mathrm{B}, \mathrm{b}}$ \\
\hline SCF-L/SCEB-L & $0.42 \pm 0.13^{\mathrm{C}, \mathrm{a}}$ & $0.48 \pm 0.13^{\mathrm{B}, \mathrm{a}}$ & $0.73 \pm 0.16^{\mathrm{A}, \mathrm{a}}$ & $0.61 \pm 0.15^{\mathrm{A}, \mathrm{a}}$ & $189.5 \pm 50.2^{\mathrm{B}, \mathrm{a}}$ & $196.1 \pm 127.2^{\mathrm{B}, \mathrm{a}}$ \\
\hline Sample & SCL & SCSH & SCL & SCSH & SCL & SCSH \\
\hline SCL-F/SCSH-F & $0.76 \pm 0.03^{\mathrm{A}, \mathrm{a}}$ & $0.75 \pm 0.07^{\mathrm{A}, \mathrm{a}}$ & $0.45 \pm 0.05^{\mathrm{B}, \mathrm{a}}$ & $0.45 \pm 0.08^{\mathrm{C}, \mathrm{a}}$ & $252.0 \pm 52.3^{\mathrm{B}, \mathrm{a}}$ & $271.16 \pm 141.1^{\mathrm{B}, \mathrm{a}}$ \\
\hline SCL-C/SCSH-C & $0.34 \pm 0.13^{\mathrm{C}, \mathrm{b}}$ & $0.72 \pm 0.13^{\mathrm{A}, \mathrm{a}}$ & $0.72 \pm 0.26^{\mathrm{A}, \mathrm{a}}$ & $0.73 \pm 0.05^{\mathrm{A}, \mathrm{a}}$ & $475.2 \pm 197.6^{\mathrm{A}, \mathrm{b}}$ & $1199.6 \pm 588.3^{\mathrm{A}, \mathrm{a}}$ \\
\hline SCL-V/SCSH-V & $0.78 \pm 0.10^{\mathrm{A}, \mathrm{a}}$ & $0.74 \pm 0.07^{\mathrm{A}, \mathrm{a}}$ & $0.60 \pm 0.02^{\mathrm{AB}, \mathrm{a}}$ & $0.56 \pm 0.03^{\mathrm{B}, \mathrm{b}}$ & $193.6 \pm 82.4^{\mathrm{B}, \mathrm{a}}$ & $162.4 \pm 53.9^{\mathrm{B}, \mathrm{a}}$ \\
\hline SCL-L/SCSH-L & $0.47 \pm 0.09^{\mathrm{B}, \mathrm{b}}$ & $0.57 \pm 0.03^{\mathrm{B}, \mathrm{a}}$ & $0.63 \pm 0.10^{\mathrm{A}, \mathrm{a}}$ & $0.50 \pm 0.02^{\mathrm{BC}, \mathrm{b}}$ & $224.6 \pm 73.5^{\mathrm{B}, \mathrm{b}}$ & $412.45 \pm 85.1^{\mathrm{B}, \mathrm{a}}$ \\
\hline Sample & $\mathrm{AB}$ & ANS4 & $\mathrm{AB}$ & ANS4 & $\mathrm{AB}$ & ANS4 \\
\hline AB-F/ANS4-F & $0.35 \pm 0.10^{\mathrm{A}, \mathrm{a}}$ & $0.29 \pm 0.03^{C, b}$ & $0.27 \pm 0.07^{\mathrm{C}, \mathrm{a}}$ & $0.18 \pm 0.05^{\mathrm{C}, \mathrm{b}}$ & $197.2 \pm 252.0^{\mathrm{B}, \mathrm{a}}$ & $26.5 \pm 15.5^{\mathrm{B}, \mathrm{b}}$ \\
\hline AB-C/ANS4-C & $0.46 \pm 0.17^{\mathrm{A}, \mathrm{a}}$ & $0.49 \pm 0.16^{\mathrm{B}, \mathrm{a}}$ & $0.74 \pm 0.10^{\mathrm{B}, \mathrm{a}}$ & $0.66 \pm 0.11^{\mathrm{A}, \mathrm{a}}$ & $690.5 \pm 601.2^{\mathrm{A}, \mathrm{a}}$ & $685.6 \pm 570.0^{\mathrm{A}, \mathrm{a}}$ \\
\hline AB-V/ANS4-V & $0.37 \pm 0.05^{\mathrm{A}, \mathrm{b}}$ & $0.68 \pm 0.12^{\mathrm{A}, \mathrm{a}}$ & $0.92 \pm 0.06^{\mathrm{A}, \mathrm{a}}$ & $0.53 \pm 0.04^{\mathrm{B}, \mathrm{b}}$ & $162.2 \pm 23.2^{\mathrm{B}, \mathrm{a}}$ & $154.8 \pm 76.8^{\mathrm{B}, \mathrm{a}}$ \\
\hline
\end{tabular}




\begin{tabular}{lllllll} 
AB-L/ANS4-L & $0.40 \pm 0.13^{\mathrm{A}, \mathrm{a}}$ & $0.31 \pm 0.06^{\mathrm{C}, \mathrm{b}}$ & $0.86 \pm 0.09^{\mathrm{A}, \mathrm{a}}$ & $0.24 \pm 0.06^{\mathrm{C}, \mathrm{b}}$ & $79.4 \pm 76.1^{\mathrm{B}, \mathrm{b}}$ & $239.3 \pm 82.8^{\mathrm{B}, \mathrm{a}}$ \\
\hline Sample & PTT & PAS & PTT & PAS & PTT & PAS \\
\hline PTT-F/PAS-F & $0.66 \pm 0.08^{\mathrm{A}, \mathrm{b}}$ & $0.79 \pm 0.04^{\mathrm{A}, \mathrm{a}}$ & $0.59 \pm 0.09^{\mathrm{B}, \mathrm{b}}$ & $0.71 \pm 0.04^{\mathrm{A}, \mathrm{a}}$ & $806.8 \pm 655.2^{\mathrm{B}, \mathrm{a}}$ & $623.1 \pm 216.5^{\mathrm{B}, \mathrm{a}}$ \\
PTT-C/PAS-C & $0.53 \pm 0.10^{\mathrm{AB}, \mathrm{a}}$ & $0.59 \pm 0.19^{\mathrm{C}, \mathrm{a}}$ & $0.50 \pm 0.18^{\mathrm{B}, \mathrm{b}}$ & $0.64 \pm 0.12^{\mathrm{A}, \mathrm{a}}$ & $1588.7 \pm 1088.0^{\mathrm{A}, \mathrm{a}}$ & $1219.1 \pm 953.0^{\mathrm{A}, \mathrm{a}}$ \\
PTT-V/PAS-V & $0.49 \pm 0.07^{\mathrm{B}, \mathrm{b}}$ & $0.64 \pm 0.15^{\mathrm{BC}, \mathrm{a}}$ & $0.76 \pm 0.36^{\mathrm{AB}, \mathrm{a}}$ & $0.63 \pm 0.06^{\mathrm{A}, \mathrm{a}}$ & $89.0 \pm 63.3^{\mathrm{C}, \mathrm{a}}$ & $107.0 \pm 60.3^{\mathrm{B}, \mathrm{a}}$ \\
PTT-L/PAS-L & $0.34 \pm 0.20^{\mathrm{C}, \mathrm{b}}$ & $0.77 \pm 0.10^{\mathrm{AB}, \mathrm{a}}$ & $0.95 \pm 0.31^{\mathrm{A}, \mathrm{a}}$ & $0.66 \pm 0.06^{\mathrm{A}, \mathrm{b}}$ & $321.1 \pm 240.5^{\mathrm{BC}, \mathrm{a}}$ & $436.7 \pm 466.2^{\mathrm{B}, \mathrm{a}}$ \\
\hline Sample & PL & PFT & PL & PFT & PL & PFT \\
\hline PL-F/PFT-F & $0.58 \pm 0.38^{\mathrm{A}, \mathrm{a}}$ & $0.47 \pm 0.14^{\mathrm{B}, \mathrm{a}}$ & $0.13 \pm 0.03^{\mathrm{C}, \mathrm{b}}$ & $0.17 \pm 0.03^{\mathrm{D}, \mathrm{a}}$ & $141.5 \pm 109.6^{\mathrm{C}, \mathrm{a}}$ & $157.9 \pm 66.1^{\mathrm{B}, \mathrm{a}}$ \\
PL-C/PFT-C & $0.67 \pm 0.18^{\mathrm{A}, \mathrm{a}}$ & $0.74 \pm 0.26^{\mathrm{A}, \mathrm{a}}$ & $0.62 \pm 0.09^{\mathrm{A}, \mathrm{b}}$ & $0.91 \pm 0.27^{\mathrm{A}, \mathrm{a}}$ & $1054.5 \pm 692.6^{\mathrm{A}, \mathrm{a}}$ & $513.5 \pm 368.7^{\mathrm{A}, \mathrm{b}}$ \\
PL-V/PFT-V & $0.67 \pm 0.18^{\mathrm{A}, \mathrm{a}}$ & $0.70 \pm 0.15^{\mathrm{A}, \mathrm{a}}$ & $0.53 \pm 0.18^{\mathrm{AB}, \mathrm{a}}$ & $0.60 \pm 0.15^{\mathrm{B}, \mathrm{a}}$ & $672.4 \pm 370.3^{\mathrm{AB}, \mathrm{a}}$ & $322.4 \pm 284.6^{\mathrm{AB}, \mathrm{b}}$ \\
PL-L/PFT-L & $0.71 \pm 0.62^{\mathrm{A}, \mathrm{a}}$ & $0.28 \pm 0.05^{\mathrm{C}, \mathrm{b}}$ & $0.45 \pm 0.16^{\mathrm{B}, \mathrm{a}}$ & $0.39 \pm 0.13^{\mathrm{C}, \mathrm{a}}$ & $400.4 \pm 400.4^{\mathrm{BC}, \mathrm{a}}$ & $616.2 \pm 342.3^{\mathrm{A}, \mathrm{a}}$
\end{tabular}

Means that do not share a letter are significantly different $(p<0.05)$

Uppercase letters A, B, C and D - differences between raw, convective dried, vacuum dried and lyophilised samples within one variety of fruit

Lowercase letters $a$ and $b$ - differences between two varieties of the same type of fruit within one drying technique 


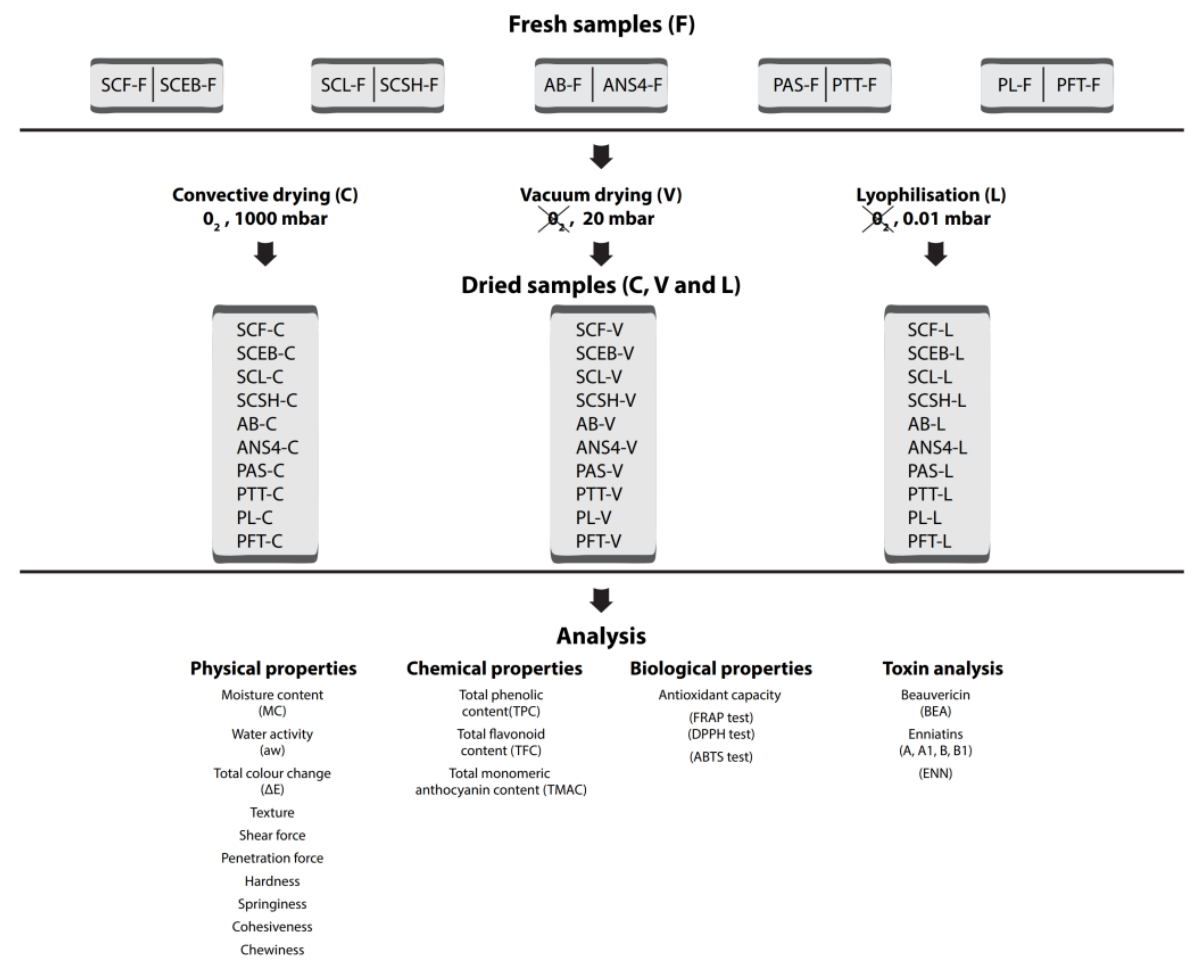

jfpp_15158_f1.tif 
Figure 2.
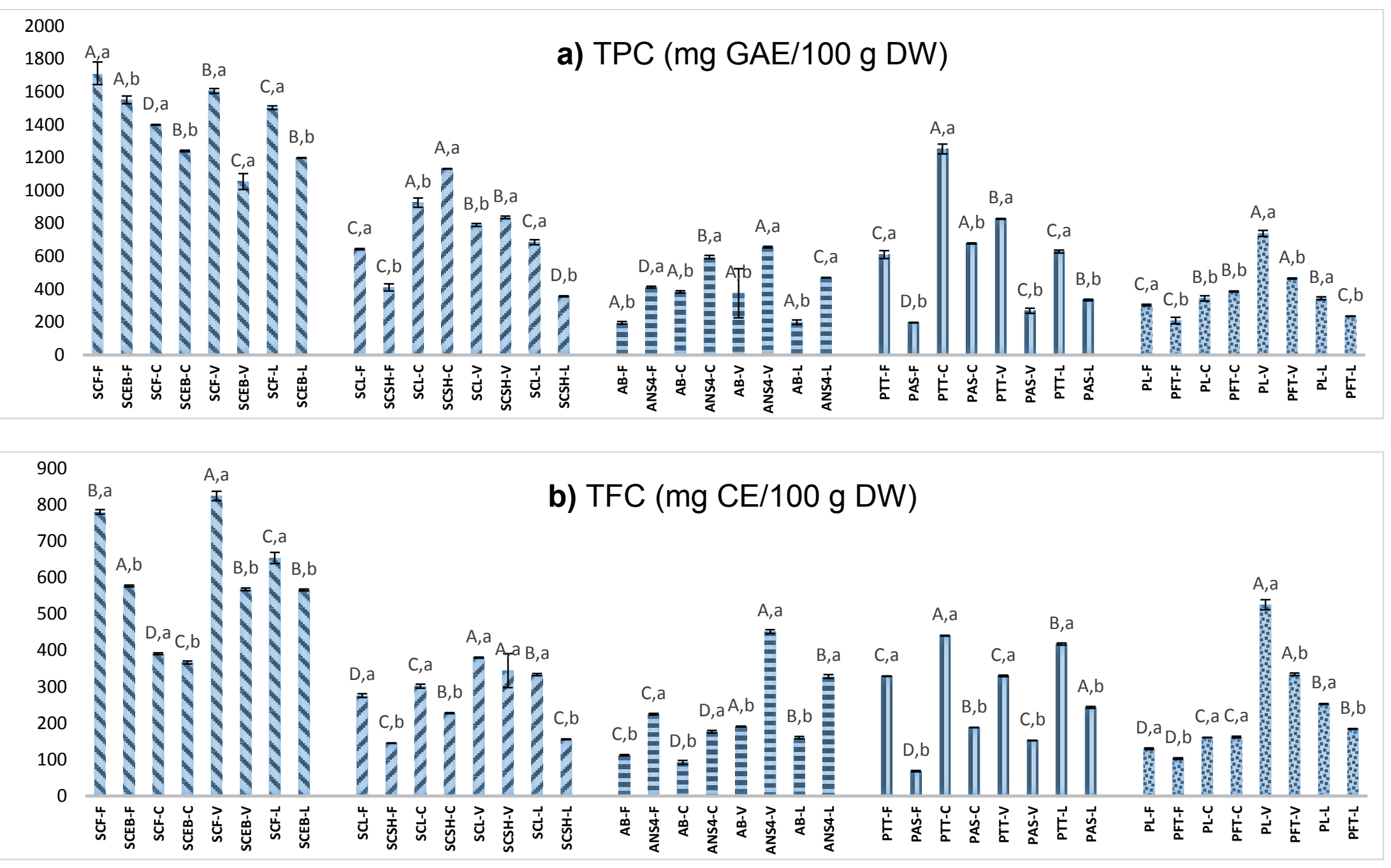


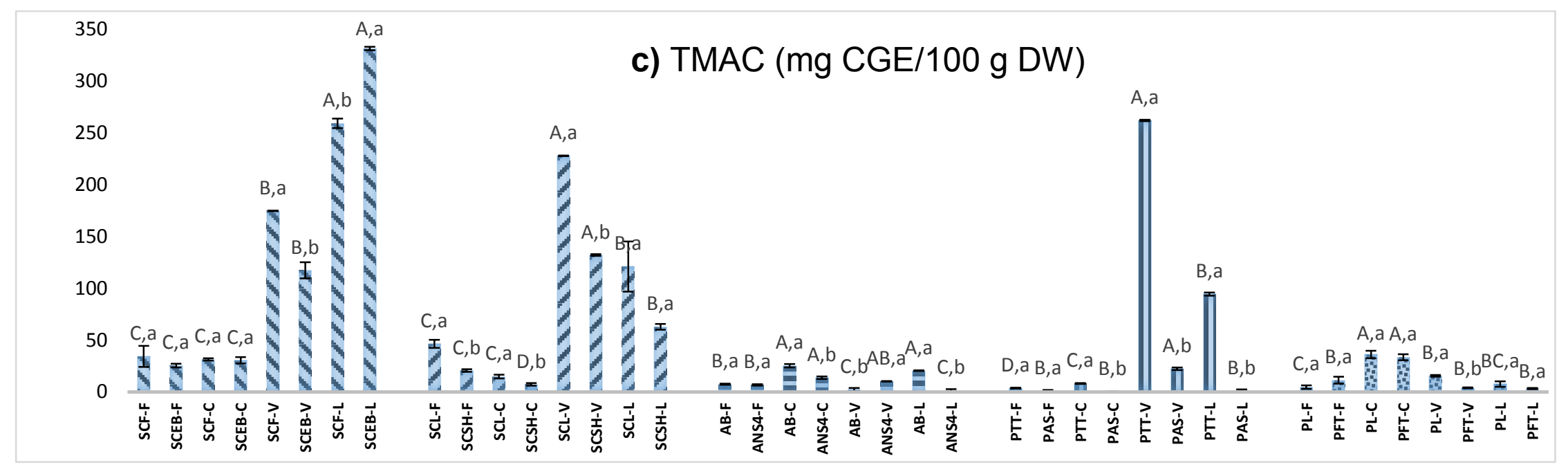

Means that do not share a letter are significantly different $(p<0.05)$

Uppercase letters A, B, C and D - differences between raw, convective dried, vacuum dried and lyophilised samples within one variety of fruit

Lowercase letters $a$ and $b$ - differences between two varieties of the same type of fruit within one drying technique 
Figure 3.
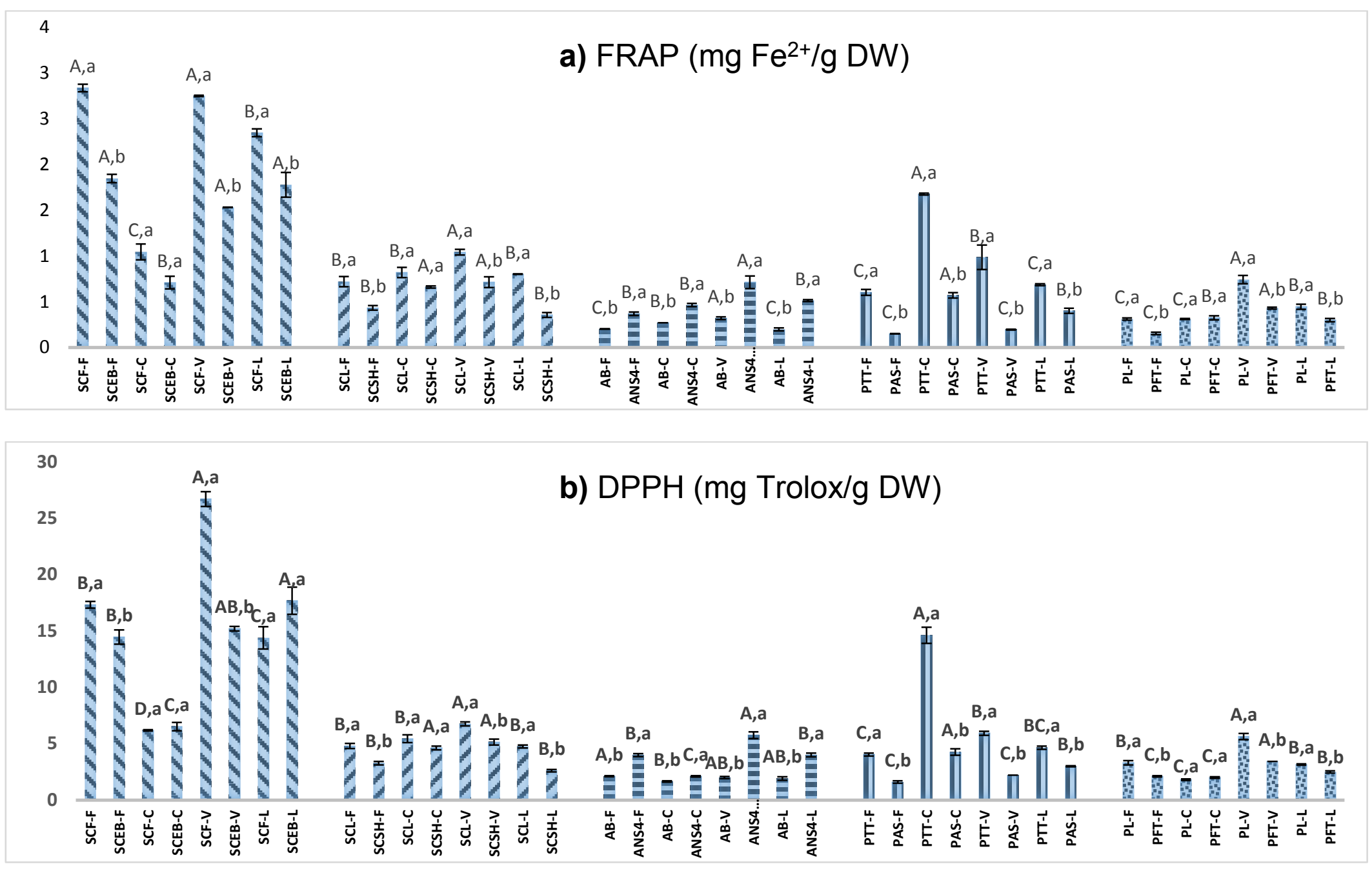


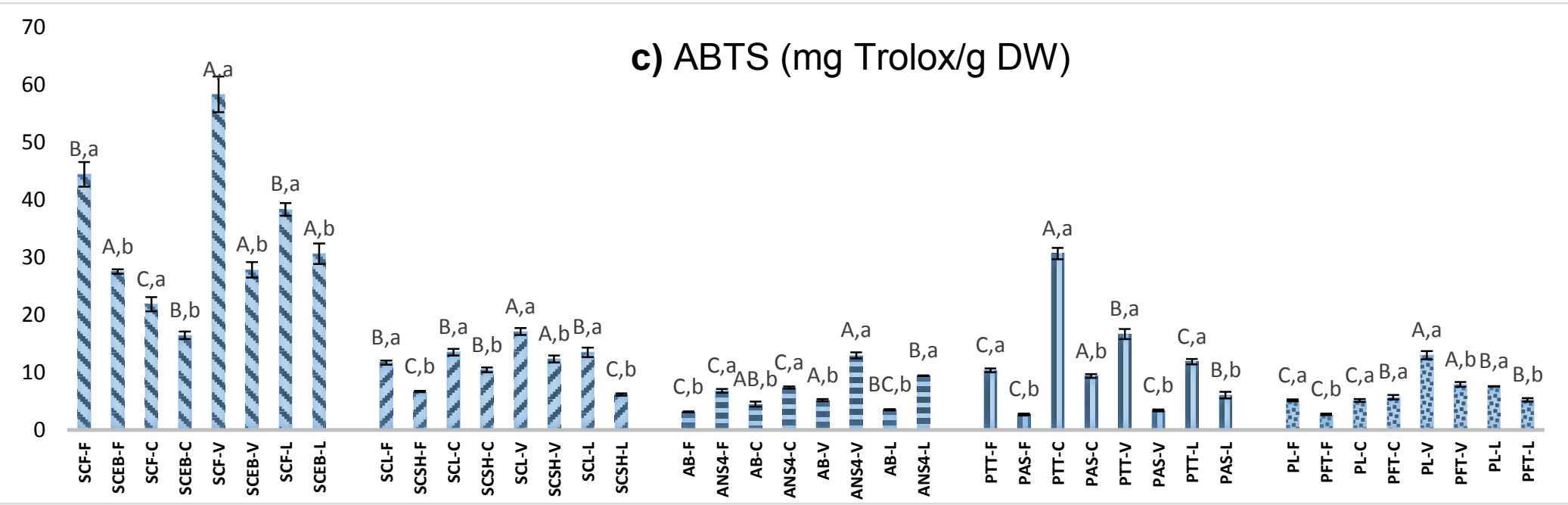

Means that do not share a letter are significantly different $(p<0.05)$

Uppercase letters A, B, C and D - differences between raw, convective dried, vacuum dried and lyophilised samples within one variety of fruit

Lowercase letters $a$ and $b$ - differences between two varieties of the same type of fruit within one drying technique 

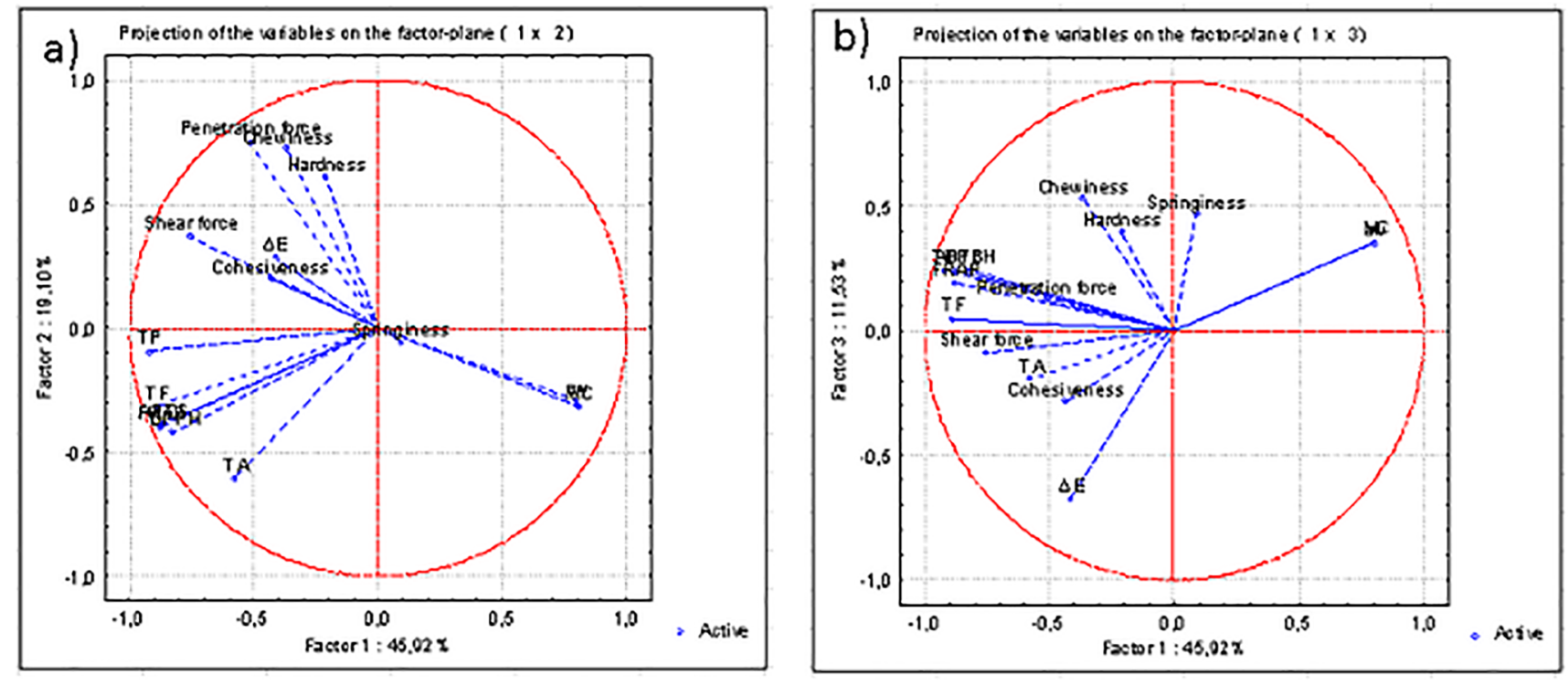

jfpp_15158_f4.tif 

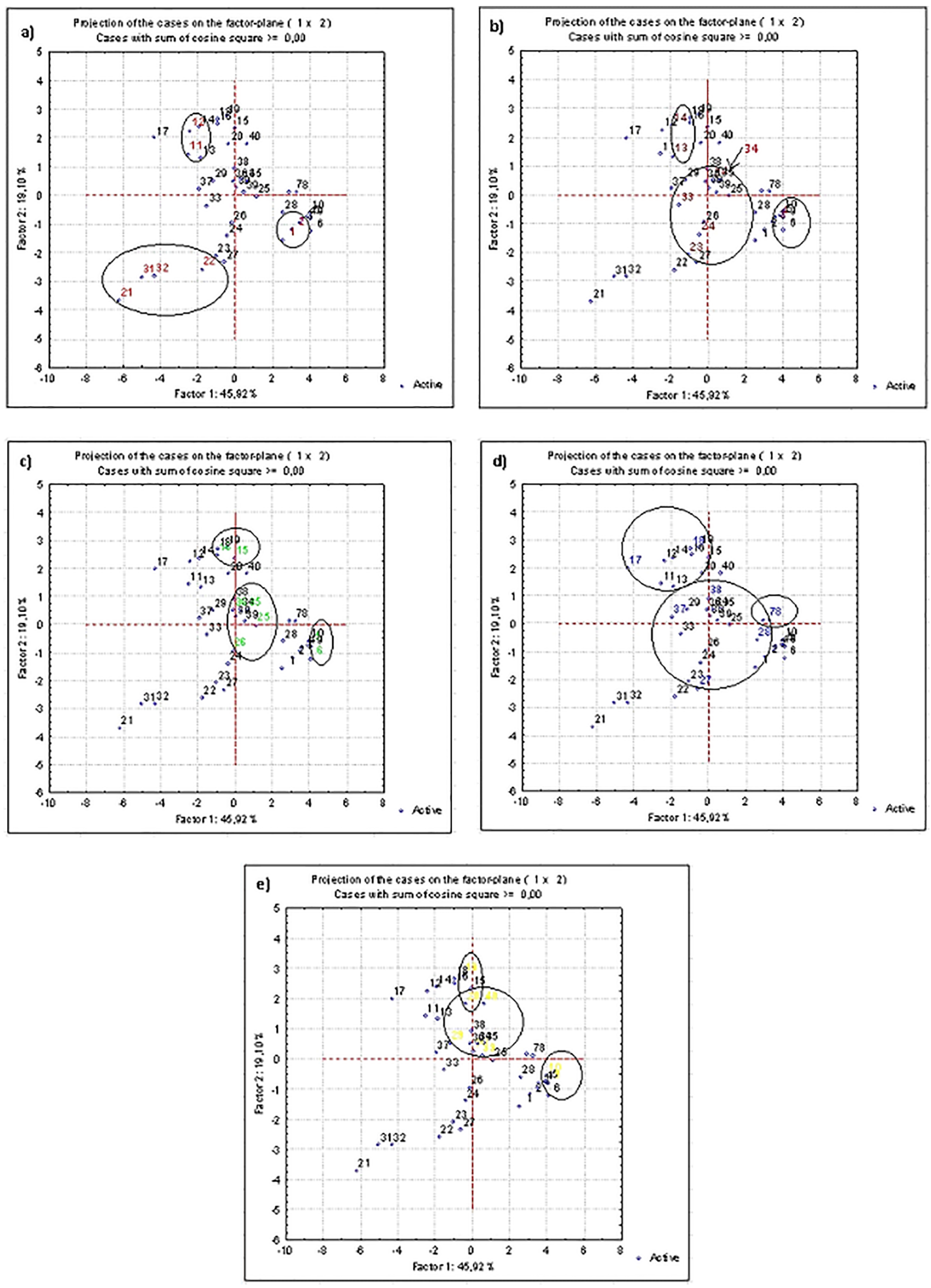